\title{
Numerical Simulation of Decontamination of Airborne Fission Products during In-Vessel Release Phase by Containment Spray
}

\author{
Khurram Mehboob \\ Department of Nuclear Engineering, Faculty of Engineering, King Abdulaziz University (KAU), P.O. Box 80204, \\ Jeddah 21589, Saudi Arabia \\ Correspondence should be addressed to Khurram Mehboob; khurramhrbeu@gmail.com
}

Received 26 October 2017; Revised 18 January 2018; Accepted 13 February 2018; Published 17 April 2018

Academic Editor: Alejandro Clausse

Copyright (C) 2018 Khurram Mehboob. This is an open access article distributed under the Creative Commons Attribution License, which permits unrestricted use, distribution, and reproduction in any medium, provided the original work is properly cited.

\begin{abstract}
The containment spray system (CSS) has a significant role in limiting the risk of radioactive exposure to the environment. In this work, the optimal droplet size and $\mathrm{pH}$ value of spray water to prevent the fission product release have been evaluated to improve the performance of the spray system during in-vessel release phase. A semikinetic model has been developed and implemented in MATLAB. The sensitivity and removal rate of airborne isotopes with the spray system have been simulated versus the spray activation and failure time, droplet size, and $\mathrm{pH}$ value. The alkaline $\left(\mathrm{Na}_{2} \mathrm{~S}_{2} \mathrm{O}_{3}\right)$ spray solution and spray water with $\mathrm{pH} 9.5$ have similar scrubbing properties for iodine. However, the removal rate from the CSS has been found to be an approximately inverse square of droplet diameter $\left(1 / d^{2}\right)$ for $\mathrm{Na}_{2} \mathrm{~S}_{2} \mathrm{O}_{3}$ and higher $\mathrm{pH}$ of spray water. The numerical results showed that $450 \mu \mathrm{m}-850 \mu \mathrm{m}$ droplet with $9.5 \mathrm{pH}$ and higher or the alkaline $\left(\mathrm{Na}_{2} \mathrm{~S}_{2} \mathrm{O}_{3}\right)$ solution with $0.2 \mathrm{~m}^{3} / \mathrm{s}-0.35 \mathrm{~m}^{3} / \mathrm{s}$ flow rate is optimal for effective scrubbing of in-containment fission products. The proposed model has been validated with TOSQAN experimental data.
\end{abstract}

\section{Introduction}

The CSS is the emergency device designed to mitigate the fission products and to maintain the containment integrity during a severe accident. The spray system is automatically activated with the initiation of the accident [1]. During an accident in a PWR, the in-containment spray system is used to prevent the containment overpressurization, to enhance the gas mixing, and to wash out fission products. The efficiency of these sprays depends on partial distribution of droplets size, droplet exposure time due to gravity, and gas phase and liquid phase mass transfer coefficients with the surrounding atmosphere $[2,3]$.

The nuclear reactor systems are sufficiently complex that there could be the possibility of an accident followed by the release of fission products. Such a release could require multiple failures of safety systems and barriers. In case of a break in the hot/cold leg in a PWR, coolant and energy were first released from the reactor coolant system to the containment through the break. The fission product also was released along with the coolant through the break. This type of accident usually occurs in the high-pressure cold leg. The worst condition of such an uncontrolled break is the guillotine type of break. In such an accident, the safety envelopes of the primary system could breach [4].

If such an accident is not controlled, core meltdown and relocation occurred, which may result in leakage of hefty radioactivity to the environment. To prevent the early overpressurization and heat load, the containment is provided by the spray system and cooling fans. The containment spray system has a significant role in enhancing the depletion of radionuclides during early in-vessel release phase. The dominant fission products that contribute to hazardous effects can be categorized as noble gases (Xe and $\mathrm{Kr}$ ), volatile (I, Cs, and $\mathrm{Te})$, semivolatile ( $\mathrm{Ru}, \mathrm{Ag}, \mathrm{Ba}, \mathrm{Sr}, \mathrm{Tc}$, and $\mathrm{Rh}$ ), and nonvolatile fission products $(\mathrm{Nb}, \mathrm{Zr}, \mathrm{Y}, \mathrm{Pd}, \mathrm{La}, \mathrm{Mo}, \mathrm{Tc}, \mathrm{Nd}$, and $\mathrm{Ce}$ ) [5]. The radioactive iodine in both elemental and gaseous forms is one of the most hazardous radionuclides due to its high yield, reactivity, environmental mobility, and potential volatility in chemical and physical forms and its significant biological hazards. Iodine may transform into volatile species and possess a complex chemistry [6]. Some isotopes are also released as particles and going through agglomeration and nucleation process forms aerosols [7]. 
In the past, the validation for the spray system has been conducted on large-scale facilities such as CVTR, NUPEC, or CES using a different type of nozzles [8-10]. The ERCOSAM project together with SAMARA project conducted the number of multistage spray system experiments along with the numerical simulation at different facilities including TOSQAN, MISTRA, PANDA, and SPOT. The major concern for these tests was to simulate the severe accident condition and to study the thermohydraulic behavior inside the containment vessel [11]. Filippov et al. (2016) have numerically investigated the two spray tests PE1 and PE2 performed at PANDA facility for code validation (FLUENT) and a better understanding of physical processes. They have modeled the gas mixture and spray flow in the multicompartment system. They have studied the penetration of helium gas between vessels due to spray operation. Their simulation results agree with the experimental results. The sixth EC framework program of severe accident research network (SARNET) was performed to evaluate the modeling of containment code as well as validation of spray models [12]. In 2013, PASSAM (passive and active system of severe accident source term mitigation) was conducted to study the radioisotope trapping techniques under severe accident conditions. The objectives of this program were to reduce the airborne radioactive species and release mechanisms of fission products from the reactor vessel through filtration systems [13]. Moreover, the TOSQAN experiment program has been developed to perform the empirical as well as simulation study of thermohydraulic condition's representatives of a severe accident condition inside the reactor containment. The several spray parameters have been studied and codes were benchmarked with TOSQAN experimental data. The purpose of the TOSQAN cold spray test was to study helium mixing due to spray activation without heat and mass transfers between gas and droplets. Porcheron et al. (2007) have studied the effect of spray injection on containment thermal hydraulic conditions and the local heat and mass transfers between spray droplets and gas [14]. Mimouni et al. (2010) have studied the TOSQAN vessel and successfully benchmarked the NEPTUNE_CFD code with TOSQAN 101 and 113 test results. They have studied the vessel depressurization, gas temperature, pressure, and gas composition. Their results have been found to be in good agreement with the TOSQAN experimental results. Several experimental studies have been conducted to understand the behavior of fission product, radioactive iodine chemistry, and its transportation [15-17].

Besides the experimentations, some researchers also developed computational models for the spray systems. Anglart et al. (2010) have studied the effect of a spray system for the cooling of reactor pressure vessel head [18]. They have developed a detailed computational model for the spray system. The model predicts the trajectories, diameters, and temperatures of subcooled droplets moving in the saturated vapor. They have also validated the model through comparison with experimental data. Porcheron et al. (2010) have conducted the numerical and experimental studies of aerosol removal with spray. They have used the ASTEC code for numerical calculations and compared the results with TOSQAN vessel results. Their results have been found to be in good agreement with the experimental data. Jain et al. (2014) have analyzed the full cone pressure swirl spray system for Indian Pressurized Heavy Water Reactor (IPHWR) [19]. They have studied the influence of Reynolds number, geometry, spray cone angle, droplet size distribution, and Sauter mean diameter (SMD). Recently, Lebel et al. (2016) have suggested the concept of a cyclonic spray system for the scrubbing of fission products of filtered containment venting [20]. They have suggested this system for passive operation of the spray system operated at low pressure having larger droplet exposure time for fission products scrubbing. Mehboob and Aljohani (2016) studied the sensitivity of iodine on containment safety parameters. They have studied the removal of iodine with the spray system. Their model was validated by the data listed in the literature. Mehboob et al. (2015) have developed a model to simulate the in-containment fission product activity as a result of LOCA. They have simulated the fission product behavior inside the reactor building for different confined safety conditions of containment. Recently, Mehboob and Aljohani (2017) have studied the effect of spray system to wash out the containment [21].

Mostly, the experimental work conducted on the spray system was focused on the gas phase mixing and transportation. The simulation research for spray operation had a major focus on the validation of codes with experimental results. However, the spray droplet and removal efficiency still have uncertainties. Therefore, in this work, the optimal droplet size and $\mathrm{pH}$ value of the spray water to prevent the fission gas release have been evaluated to improve the performance of the spray system in PWR during in-vessel release phase. The modeling and simulation have been carried out in two stages. First, the fission product inventory is evaluated by ORIGEN2.2 code for one complete fuel cycle. The postaccident conditions are implemented in the developed model that uses the ORIGEN2.2 code as subroutine code. The simulation has been carried out for static in-containment atmospheric conditions by considering the continuous release of fission products from the reactor pressure vessel along with the coolant.

\section{Spray System in NPPs}

2.1. Spray System in LWRs. The PWRs encompass more than two-thirds of operating light-water reactors worldwide and have one to two orders of magnitude of coolant and steam generation fission product inventory compared to other reactors. The PWRs designed by the Framatome (Areva), Westinghouse, and others are equipped with the containment spray system. In most NPPs, the spray system is activated with the increase in containment pressure from the preset value. These reactors use the spray system for the containment depressurization and fission product scrubbing [22]. The French-designed PWR containments have a free volume between $60,000 \mathrm{~m}^{3}$ and $70,000 \mathrm{~m}^{3}$ and mostly are large dry containments. These containments generally have two or more circular rings of spray nozzles. The rings of $12 \mathrm{~m}$ diameter at the height of $54 \mathrm{~m}$ with about 70 nozzles are used for spray at the middle of the containment. The 2 nd ring of diameter of $27 \mathrm{~m}$ at height of approximately $51 \mathrm{~m}$ is equipped with 186 spray nozzles used to spray inside and on the walls [3]. 


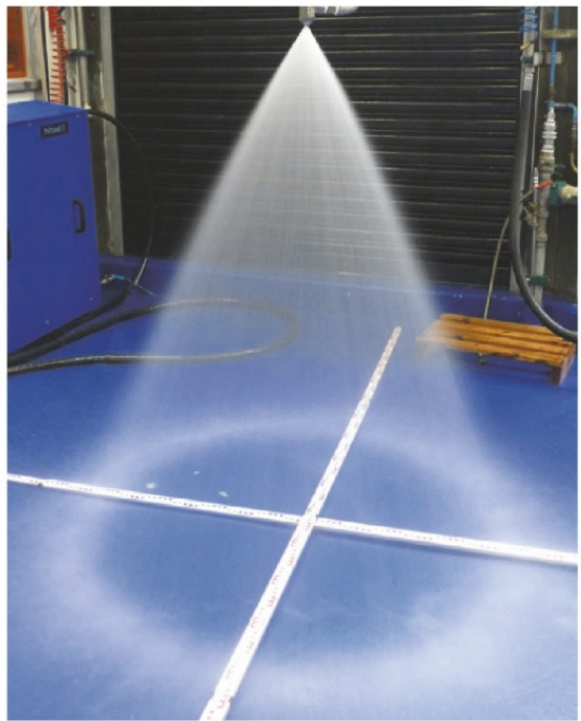

(a)
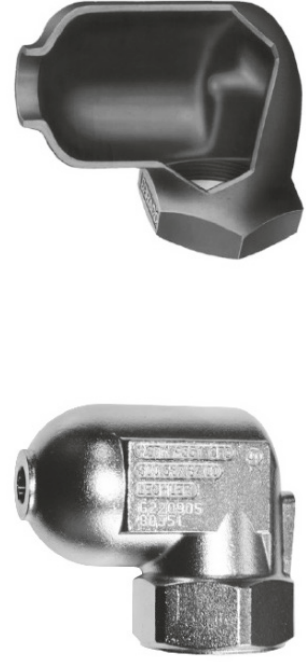

(b)

FIgURE 1: A design of hollow cone nozzle 1713-A by Lechler (b) and hollow cone spray pattern (a) [23].

The spray nozzles installed in 900 MWe French PWRs are called SPARCO 1713-A distributed by Lechler (Figure 1), whereas the other designs are installed with 373 series [23]. This type of nozzle is operated at $3.56 \mathrm{MPa}$ and generated a spray with inlet flow rate of $1.667 \times 10^{-5} \mathrm{~m}^{3} / \mathrm{s}$ [23]. The outlet orifice's diameter is $9.5 \mathrm{~mm}$. The injected water temperature range is from $20^{\circ} \mathrm{C}$ to $60^{\circ} \mathrm{C}$. The spray system is operated when the containment pressure reached $0.25 \mathrm{MPa}$. After 30 minutes, recirculation mode is activated, in which spray system is fed through the sump via a heat exchanger to reduce the spray water temperature to $60^{\circ} \mathrm{C}$.

2.2. Spray System in Russian Designed LWRs. The VVER440/213 and VVER-1000/320 are the common Russian design plants. The containment design of these plants has a free volume of $50,000 \mathrm{~m}^{3}$ to $60,000 \mathrm{~m}^{3}$. The VVER- $440 / 213$ pressurized water reactors are equipped with bubble condenser containment for the removal of radioactivity released as a result of an accident [24]. The containment of VVER$440 / 213$ consists of the intercompartments system that surrounds the complete primary system and a pressure retaining bubble condenser system comprising a complex pressuresuppression system. The bubble condenser system reduces the pressure of the entire containment during an accident condition such as LOCA.

The VVER containment is equipped with three independent trains installed with about 65 nozzles per train. The mass flow rate through the nozzle is about $0.016 \mathrm{~m}^{3} / \mathrm{s}$. The steam generator compartment of $+6 \mathrm{~m}$ from the ground is equipped with the various equipment and the spray droplets interact with this equipment before hitting the ground. The spray nozzles are installed at various angles to increase the spray volume. Therefore, full cone type nozzles are installed in VVER stream generator compartment. The typical full cone nozzle is shown in Figure 2. The spray system is first fed from the tank, and then it is switched to the sump through heat exchanger when the tank is empty.

The VVER-1000/320 containment is similar to the European design containment system. It is a can type containment system with various spray nozzles trains like VVER-400. The three independent trains are located at $55 \mathrm{~m}, 60 \mathrm{~m}$, and $65 \mathrm{~m}$ from the floor. There are around 20 nozzles on each train. The nozzle mass flow rate is $0.0083 \mathrm{~m}^{3} / \mathrm{s}$ and is operated at $0.2 \mathrm{MPa}$. The nozzles are installed at different angles similar to VVER-400 installation. The spray system is constantly fed with the sump which is always filled with water. The water is fed through the heat exchanger to remove the residual heat $[3,25]$.

2.3. Spray System in Boiling Water Reactors (BWRs). In Boiling Water Reactors (BWRs), MARK-III containment is equipped with three independent trains with more than 300 spray nozzles mounted on the headers. In MARK-III, containment spray system is provided with two pumps. A single pump supplies about 356 liters/s of water. Altogether, both pumps could provide a mass flow rate of $0.527 \mathrm{~m}^{3} / \mathrm{s}$. The three independent trains of diameters of $5.87 \mathrm{~m}, 12.11 \mathrm{~m}$, and $16.48 \mathrm{~m}$ are located at $25 \mathrm{~m}, 22 \mathrm{~m}$, and $16 \mathrm{~m}$ from the vessel head. A Sprayco Model 1713-A or 1713 nozzles are widely used in BWRs. The vendor of these nozzles is Lechler Corporation. The designation of the nozzle is 373.084.xx.BN hollow cone, ramp bottom, and standard angle spray nozzle [26].

\section{Simulation Model}

3.1. Description of Plant Model. In this study, we have selected a typical conventional PWR design. A conventional PWR of 1000 MWe system has steam generators (SG), a reactor 


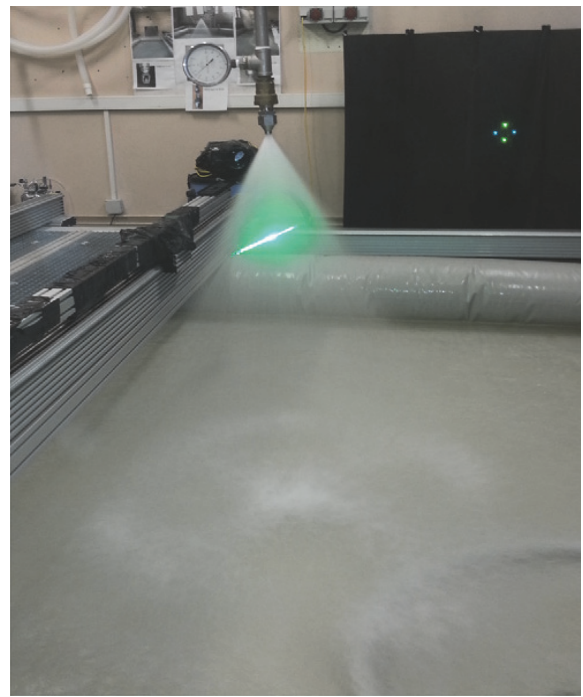

(a)

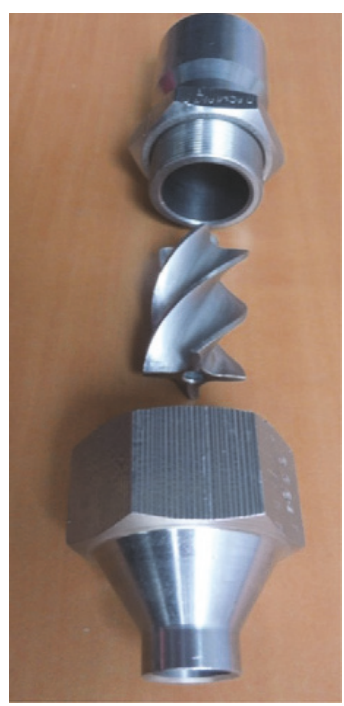

(b)

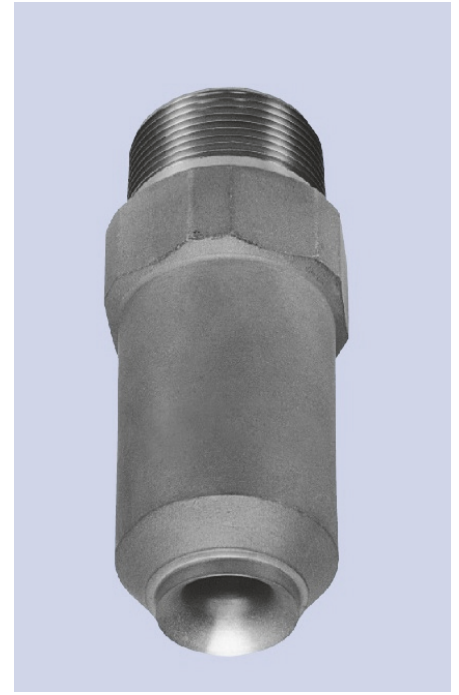

(c)

FIGURE 2: A single full cone spray (a) with VVER nozzle (b) and a full come designed by Lechler (c) $[3,23]$.

pressure vessel (RPV), coolant pump, and a pressurizer. The conventional PWR of 1000 MWe has two loops with two cold legs, one hot leg, and two reactor coolant pumps (RCPs) for each loop and a pressurizer connected to one of the hot legs. The secondary loop has feedwater system which contains startup feedwater system, main steam generating system, and safety valves of steam generators. The primary safety systems for reactor core include Emergency Core Cooling System (ECCS), accumulators, Residual Heat Removal (RHR), Core Makeup Tanks (CMTs), and in-containment Refueling Water Storage Tank (IRWST).

The standard fuel enrichment of the core is almost $2.5 \mathrm{wt} \%$ weight of uranium. The reactor core design contains 193 assemblies, with 76 control rod assemblies including 5 instrumentation control assemblies. The height of the reactor vessel is $1242 \mathrm{~cm}$ with $366 \mathrm{~cm}$ active core length, which can contain $113.55 \mathrm{~m}^{3}$ water volume. The flux distribution and power of core are controlled with 1420 control rods. The pitch of fuel rods is $1.443 \mathrm{~cm}$, whereas the outer diameter of the fuel rod is $1.092 \mathrm{~cm}$. The key design features of a typical $1000 \mathrm{MWe}$ system are depicted in Table 1 [27, 28]. The schematic diagram of PWR containment with a spray system is depicted in Figure 3.

3.2. Loss of Coolant Accident (LOCA). A hypothetical uncontrolled LOCA has been considered to study the effect of the spray system on airborne fission product masses inside the containment building. The continuous leakage of coolant from the reactor pressure vessel during in vessel release phase has been modeled. The uncontrolled LOCA has a probability of $9 \times 10^{-7}$ to $4 \times 10^{-6}$ per year [29]. In such an accident, $10 \%$ to $40 \%$ core could be damaged $[29,30]$. During large break LOCA, the temperature and pressure inside the containment are defined by the steam generation rate, cooling rate, and the geometry of the containment vessel. It is expected that
TABLE 1: Design parameters of 1000 MWe PWR [27, 28].

\begin{tabular}{lc}
\hline Parameter & Value \\
\hline Reactor & $\mathrm{PWR}$ \\
Fuel type & $\mathrm{UO}_{2}$ \\
Average fuel enrichment wt $\%$ & $2.5 \%$ \\
Core-specific power $(\mathrm{MWth} / \mathrm{kg} \mathrm{U})$ & 33.3 \\
Core power density $\left(\mathrm{MWth} / \mathrm{m}^{3}\right)$ & 66.6 \\
System pressure $(\mathrm{MPa})$ & 15.166 \\
Reactor coolant system pressure $(\mathrm{MPa})$ & 14.96 \\
Reactor coolant flow $(\mathrm{kg} / \mathrm{s})$ & 17387.7 \\
Vessel height $(\mathrm{m})$ & 12.41 \\
Core active region height $(\mathrm{m})$ & 3.65 \\
Core diameter $(\mathrm{m})$ & 3.81 \\
Fuel rod assemblies & 193 \\
Control rod assemblies & 76 \\
Cladding material & Zircaloy \\
Fuel rod outer diameter $(\mathrm{cm})$ & 1.092 \\
Rod pitch (cm) & 1.443 \\
Fuel assembly matrix & $17 \times 17$ \\
Coolant inlet temperature $(\mathrm{K})$ & 564.81 \\
Coolant outlet temperature $(\mathrm{K})$ & 592.98 \\
Control rods & 1420 \\
Control rod material & $(50 \%)-\mathrm{In}(15 \%)-\mathrm{Cd}$ \\
\hline
\end{tabular}

the pressure and temperature inside the containment reach $0.154 \mathrm{MPa}$ and $80^{\circ} \mathrm{C}$ soon after the accident [31, 32]. To generate the hypothetical uncontrolled LOCA, Emergency Core Cooling System (ECCS), accumulators, core, Residual Heat Removal (RHR), Core Makeup Tanks (CMTs), and in-containment Refueling Water Storage Tank (IRWST) are 


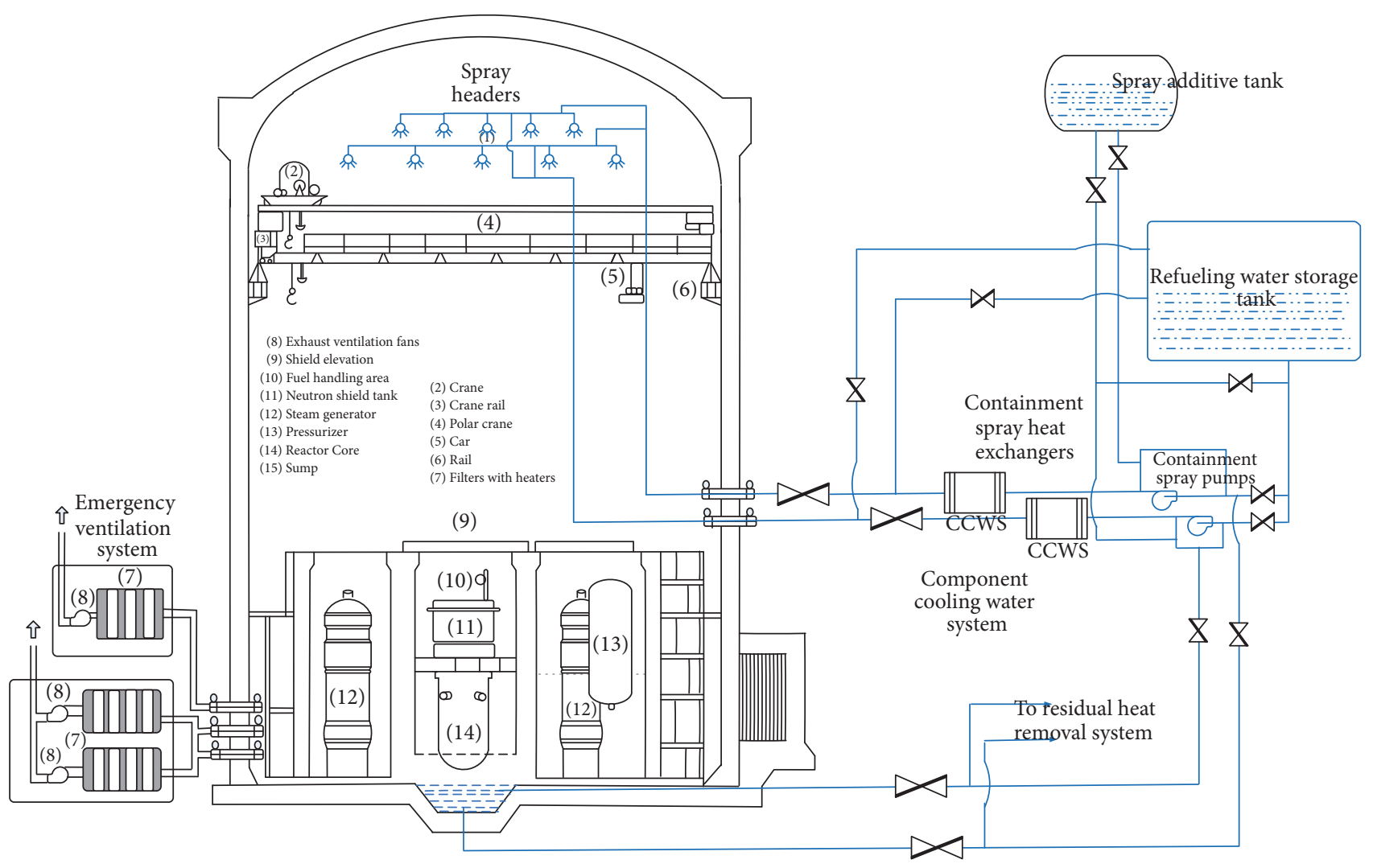

FIGURE 3: A schematic diagram of a typical PWR system with the containment spray system.

TABLE 2: Consequences and events in LOCA for simulation.

\begin{tabular}{lc}
\hline LOCA event & Time $(\mathrm{s})$ \\
\hline Large break in the cold leg & $0 \mathrm{~s}$ \\
Reactor trip & $2 \mathrm{~s}$ \\
Start of spray system & $t=100 \mathrm{~s}, 500 \mathrm{~s}$, \\
LIPS activation & $1000 \mathrm{~s}, 1500 \mathrm{~s}$ \\
Release of fission product to primary & $\cong 260 \mathrm{~s}$ \\
circuit & Immediate \\
Uncovered core & $\cong 1800 \mathrm{~s}$ \\
PRV failure & $\cong 3700 \mathrm{~s}$ \\
\hline
\end{tabular}

assumed to malfunction, which could result in core damage. Simulation of the droplet interaction with gas phase and liquid phase has been carried out at same pressure and temperature. The accident sequence is listed in Table 2.

3.3. In-Containment Fission Product Model. A real-time kinetic model has been developed to simulate the effect of spray system on radioactive released mass inside the containment. The arithmetic model is a set of coupled Ordinary Differential Equations (ODEs). The continuous source of airborne mass is the instant release of radioactive mass from the reactor pressure vessel along with coolant and resuspension from different surfaces. The loss in airborne concentration is due to the natural decay, with spray, with recirculation filtration, leakage or bypass from containment, and deposition of isotopes on the walls and other surfaces. If the airborne concentration of mass of the $i$ th isotope is defined as $m_{v, i}(t)$ in $\mathrm{g} / \mathrm{m}^{3}$, then mass concentration released inside the containment can be expressed as [29, 33, 34].

$$
\begin{aligned}
\frac{d m_{v, i}(t)}{d t}= & -\lambda_{i} m_{v, i}(t)-u_{t, i} \frac{S}{V} m_{v, i}(t)-\frac{H \eta_{i} F}{V} m_{v, i}(t) \\
& -\frac{3 h F E_{a}}{2 d V} m_{v, i}(t)-R_{\mathrm{res}, i} \frac{\eta_{r c}}{V} m_{v, i}(t) \\
& -\frac{L_{r}}{V} m_{v, i}(t)+r_{i} \frac{S}{V} m_{s, i}(t)+P_{i}(t),
\end{aligned}
$$

where $\lambda$ is decay constant, $u_{t}$ is terminal velocity, $H$ is partition coefficient, $F$ is spray flow rate, $L_{r}$ is leakage rate, $R_{\text {res }}$ is filters recirculation rate, $d$ is droplet diameter, $V$ is containment volume, $r$ is resuspension rate, $S$ is containmentfree surface, and $P(t)$ is the time-dependent source term. In this model, we have ignored the droplet collision and agglomeration and we have considered the containment as a single volume. The values of above-mentioned parameters have been listed in Table 3. The spray removal rate for iodine can be expressed as [29]

$$
\eta_{i}=1-\exp \left[-6 \frac{K_{G} \times t_{d}}{d \times\left(H+K_{G} / K_{L}\right)}\right]
$$


TABLE 3: Important parameters used for simulation [35].

\begin{tabular}{lcc}
\hline Parameter & Symbol & Value \\
\hline Containment-free volume & $V\left(\mathrm{~m}^{3}\right)$ & 57600 \\
Containment-free surface & $S\left(\mathrm{~m}^{2}\right)$ & $\sim 34374$ \\
Leakage rate & $L_{r}\left(\mathrm{~m}^{3} / \mathrm{s}\right)$ & 14.15 \\
Core damage fraction & $f_{c}(\%)$ & $35 \%$ \\
Fuel release fraction & $f_{f}(\%)$ & $9.0 \times 10^{-1}$ \\
Water release fraction & $f_{p}(\%)$ & $3.00 \times 10^{-1}-1.0 \times 10^{2}$ \\
Recirculation rate & $R_{\mathrm{res}}\left(\mathrm{m}^{3} / \mathrm{s}\right)$ & $1-5$ \\
Recirculation filtration efficiency & $\eta_{\mathrm{res}}(\%)$ & $10 \%-90 \%$ \\
Exhaust filter efficiency & $\eta_{\mathrm{ex}}(\%)$ & $90-98$ \\
Fraction of immediately released radioisotopes & $f_{x}(\%)$ & $2.0 \times 10^{-1}$ \\
Mixing rate & $w_{x}\left(\mathrm{~s}^{-1}\right)$ & $0.1-1.0$ \\
Spray flow rate & $F\left(\mathrm{~m}^{3} / \mathrm{s}\right)$ & $0.1-1.0$ \\
Droplet size & $d\left(\mathrm{micron}^{2}\right)$ & $100-1000$ \\
Deposition velocity $\left(u_{d}\right)$ & $(\mathrm{m} / \mathrm{s})$ & $5.5 \times 10^{-4}$ \\
Resuspension rate & $\mathrm{s}$ & $\leq 2.3 \times 10^{-1}$ \\
\hline
\end{tabular}

TABLE 4: Numerical data for spray removal term $[31,35,36]$.

\begin{tabular}{lcc}
\hline Parameter & Symbol & Value \\
\hline Partition coefficient & $H$ & $200\left(\mathrm{pH}_{5.0}\right), 5000\left(\mathrm{pH} \mathrm{9.5)} 10,000\left(\mathrm{Na}_{2} \mathrm{~S}_{2} \mathrm{O}_{3}\right)\right.$ \\
Reynolds number & $\mathrm{Re}$ & 1.29 \\
Schmidt number & $\mathrm{Sc}$ & 1.742 \\
Molar weights of solvent & $\mathrm{Ml}(\mathrm{g} / \mathrm{mole})$ & 18.01528 \\
Temperature & $v\left(\mathrm{~cm}^{3} / \mathrm{g}\right)$ & $80+273.15$ \\
Molecular volume of $\mathrm{I}_{2}$ & $\mu l(\mathrm{centipoise})$ & 71.5 \\
Viscosity & $F\left(\mathrm{~m}^{3} / \mathrm{sec}\right)$ & 0.35 \\
Spray flow rate & $x$ & 0.35 \\
Degree of solvent & & 2.6 for $\mathrm{H}_{2} \mathrm{O}$ \\
\hline
\end{tabular}

where $t_{d}$ is droplet exposure time and $K_{G}$ and $K_{L}$ are the gas phase and liquid phase mass transfer coefficients and they are expressed as follows [32]:

$$
\begin{aligned}
& K_{G}=\frac{D_{L}}{d}\left\{2.0+0.60 \times \mathrm{Re}^{0.5} \times \mathrm{Sc}^{0.33}\right\}, \\
& K_{L}=\frac{2 \pi^{2} D_{L}}{3 d} .
\end{aligned}
$$

Here Re is Reynolds number; Sc is Schmidt number; $D_{L}$ is the diffusion of iodine in spray droplets and is depicted as follows [29, 31]:

$$
D_{L}=\frac{\left(7.4 \times 10^{-8}\right) \times \sqrt{\left(x M_{l}\right)} \times T}{\mu_{l} v^{0.6}}
$$

where $x$ is a degree of solvent; $v$ is the molecular volume of diffusing elemental iodine; $M_{l}$ is the solvent molar weight and $\mu_{l}$ is the viscosity of liquid water at temperature $T$. The computational values used for above-mentioned parameters are listed in Table 4.

The concentration of radioisotopes on containment surfaces also has the gain and loss terms. If $m_{s}(t)$ is the concentration of radioactive isotopes on free surfaces, then the rate of change in concentration of radioactive isotopes on free surfaces is depicted as

$$
\frac{d m_{s}(t)}{d t}=u_{t} m_{v}(t)-r m_{s}(t) .
$$

The 1 st term is the rate of deposition of $i$ th isotope on surfaces. The 2 nd term is regaining of the $i$ th isotope due to resuspension. The concentration of radioactive mass on containment surfaces is assumed to be zero before the progression of the accident; that is, $m_{s}(t)=0 \mathrm{~kg} / \mathrm{m}^{2}$. The puff release of radioactive material is limited to the fission products presented to the coolant. The instantaneous airborne mass with the puff release is $m_{v}(t)=f_{x} \times f_{f} \times f_{p} \times$ $f_{c} \times A_{c} / V \mathrm{~g} / \mathrm{m}^{3}$, where $f_{x}$ is the fraction of radioisotopes that instantaneously became aerial with the puff release. The remaining fractional part contributes to containment concentration along with the coolant leakage with mixing through coolant as a function of time, where $f_{p}$ is the coolant release fraction; $f_{c}$ is the core damage fraction; $f_{f}$ is fuel release fraction and $A_{c}$ is the total core inventory.

In this study, we have implemented only $20 \%$ of inventory as the instantaneous airborne concentration of isotopes with the puff release. Since as the break occurs the leakage of coolant through the break immediately reaches $\sim 5200 \mathrm{~kg} / \mathrm{s}$ 
TABLE 5: Comparison of core and coolant inventory for selected isotopes.

\begin{tabular}{|c|c|c|c|c|c|c|}
\hline \multirow{3}{*}{ Nuclide } & \multicolumn{3}{|c|}{ Reactor core inventory } & \multicolumn{3}{|c|}{${ }^{*}$ Coolant inventory } \\
\hline & & Grams & & & Grams & \\
\hline & Our plant & ${ }^{\dagger}$ KORI -1 & ${ }^{\dagger \dagger} \mathrm{AP}-1000$ & Our plant & ${ }^{\dagger}$ KORI-1 & ${ }^{\dagger \dagger} \mathrm{AP}-1000$ \\
\hline $\mathrm{I}-131$ & $6.13 E+02$ & $2.00 E+02$ & $7.76 E+02$ & $8.65 E+00$ & $1.43 E+00$ & $1.73 E+01$ \\
\hline $\mathrm{I}-133$ & $1.30 E+02$ & $4.19 E+01$ & $1.76 E+02$ & $2.29 E+00$ & $3.17 E+00$ & $3.10 E+00$ \\
\hline Cs-137 & $1.08 E+05$ & $2.66 E+04$ & $1.30 E+05$ & $2.83 E+00$ & $1.40 E-01$ & $3.36 E+00$ \\
\hline Sr-90 & $4.48 E+05$ & $1.54 E+04$ & $1.33 E+06$ & $4.60 E+01$ & $8.36 E-02$ & $1.43 E+01$ \\
\hline Kr-85 & $1.93 E+03$ & $6.67 E+02$ & $2.70 E+03$ & $1.01 E-02$ & $9.85 E-03$ & $1.24 E-02$ \\
\hline $\mathrm{Kr}-88$ & $3.08 E+00$ & $2.03 E+00$ & $5.69 E+00$ & $4.76 E-03$ & $4.82 E-02$ & $2.02 E-03$ \\
\hline $\mathrm{Xe}-133$ & $7.87 E+02$ & $2.97 E+02$ & $1.01 E+03$ & $4.07 E+01$ & $3.25 E+00$ & $1.15 E+01$ \\
\hline $\mathrm{Xe}-135$ & $1.12 E+01$ & $3.82 E+00$ & $1.89 E+01$ & $4.31 E-01$ & $5.41 E-01$ & $2.37 E+00$ \\
\hline
\end{tabular}

${ }^{\dagger \dagger}$ Zhao et al. (2015); ${ }^{\dagger}$ Kim and Kang (1999) [41]. ${ }^{*} 0.025$ fail fuel fraction.

within four seconds, most of the radioactive elements available in reactor coolant became airborne with the puff release. Although the coolant leakage rate is significantly high, only $25 \%$ coolant could leak with the puff release within first few seconds of the break. After the puff phase, coolant leakage decreases and reaches $50 \mathrm{~kg} / \mathrm{s}[22,37]$. Furthermore, the puff release of radioactive material is limited to a number of fission products presented in the coolant [22]. The remaining part of radioisotopes contributes to containment atmosphere along with leakage of coolant with mixing rate $w_{x}$. Thus, the kinetic source $P(t)$ can be explained as follows [38]:

$$
P(t)=\left(1-f_{x}\right) A_{c} f_{f} f_{p} f_{c} \frac{B}{V} e^{\left(-w_{x} t\right)} .
$$

$\left(1-f_{x}\right) \exp \left(-w_{x} t\right)$ is the part of radioactivity that contributes to containment airborne concentration along with the coolant leakage with mixing rate $w_{x}$. The airborne concentration of radioactive mass inside the containment decreases exponentially because of nucleation, chemical interaction, deposition, and so forth. Thus, the leakage of radioactive mass from the reactor pressure vessel is expressed with a negative exponent of time and mixing rate (see (6)). The overall radioactive mass inventory including kinetic and static part is depicted in (7). The 1st term is the concentration of radioactive mass which leaks along with the puff release and second term is the kinetic term that contributes along with the coolant with mixing rate.

$$
\begin{aligned}
A_{c} & =f_{x} A_{c}+\left(1-f_{x}\right) A_{c} B \int_{0}^{T} e^{-w_{x} t} d t, \\
B & =\frac{w_{x} \times\left(w_{x} / T\right)}{w_{x}-w_{x} / T},
\end{aligned}
$$

where $B$ is the normalization constant that became roughly equal to mixing rate $w_{x}$ for a large time interval $\left(t=10 / w_{x}\right)$. The removal of $i$ th iodine isotopes by the containment spray system can be expressed as first-order differential equation, which equates the rate of mass accumulation in containment atmosphere to the difference between the source and removal rates [39]:

$$
\frac{d m_{r, i}(t)}{d t}=P_{i}(t)-\frac{H \eta_{i} F}{V} m_{v, i}(t)
$$

where $m_{r, i}$ is the removal rate of $i$ th isotope of iodine; $P_{i}$ is the continuous source of $i$ th isotope of iodine. The removal rate of particulate " $m r a, i$ " is expressed by the following equation:

$$
\frac{d m_{r a, i}(t)}{d t}=P_{i}(t)-\frac{3 h F E_{a}}{2 d V} m_{v, i}(t),
$$

where $m_{r a}$ is the removal rate of aerosols and $E_{a}$ is the collection efficiency of aerosols. The value of $E_{a}$ has been taken from NUREG/CR-009. The developed code that is implemented in MATLAB is depicted in Figure 6.

\section{Computational Technique}

To study the effect of the spray system on in-containment fission product scrubbing, the multistage methodology has been adopted. The core inventory of $1000 \mathrm{MWe}$ PWR for one complete cycle has been evaluated using ORIGEN2.2 code [40]. The coolant activity has been evaluated at the end of the fuel cycle. The core and coolant inventories have been compared with the inventories listed in literature [29], AP1000 and KORI-1 PWRs. The comparison of selected isotopes is listed in Figure 8 and Table 5. The fission product release fraction is depicted in Table 6. The break is introduced at the end of the fuel cycle and continuous release of fission products from fuel to coolant and from coolant to containment is modeled and implemented in MATLAB. The continuous leakage of fission products along with the leakage of coolant is simulated and airborne concentration of fission product in containment is determined by solving the coupled ODEs. The Runge-Kutta 4th-order method is implemented to solve the coupled ODEs. To study the effect of the containment spray system, the spray is activated at various time after the accident and containment spray conditions are selected for $\mathrm{pH} 5.0$ and 9.5 and for alkaline spray solution. The flow diagram of incontainment source term estimation is depicted in Figure 4.

4.1. Implementation in MATLAB. In this work, the effect of the spray system on the in-containment fission product during in-vessel release phase has been studied. The modeling and simulation have been carried out in MATLAB. A computer program is generated in MATLAB to compute the 
TABLE 6: PWR accidental fission products release fractions in LOCA.

\begin{tabular}{|c|c|c|}
\hline \multirow[b]{2}{*}{ Nuclide group } & \multicolumn{2}{|c|}{ PWR release fraction } \\
\hline & $\begin{array}{l}\text { Cladding failure (cladding gap release) } \\
\qquad(0.5 \mathrm{~h})\end{array}$ & $\begin{array}{c}\text { Core melt (in-vessel release) } \\
\text { (1.3 hours) }\end{array}$ \\
\hline Noble gases $(\mathrm{Kr}, \mathrm{Xe})$ & 0.05 & 0.95 \\
\hline Halogens (I, Br) & 0.05 & 0.35 \\
\hline Alkali metals (Cs, Rb) & 0.05 & 0.25 \\
\hline Tellurium group $(\mathrm{Te}, \mathrm{Sb}, \mathrm{Se})$ & 0 & 0.05 \\
\hline Barium, strontium (Ba, Sr) & 0 & 0.02 \\
\hline Noble metals (Ru, Rh, Pd, Mo, Tc, and Co) & 0 & 0.0025 \\
\hline Cerium group (Ce, $\mathrm{Pu}, \mathrm{Np})$ & 0 & 0.0005 \\
\hline $\begin{array}{l}\text { Lanthanides (La, Zr, Nd, Eu, Nb, Pm, Pr, Sm, Y, Cm, and } \\
\text { Am) }\end{array}$ & 0 & 0.0002 \\
\hline
\end{tabular}

Data from Soffer et al. (1995).

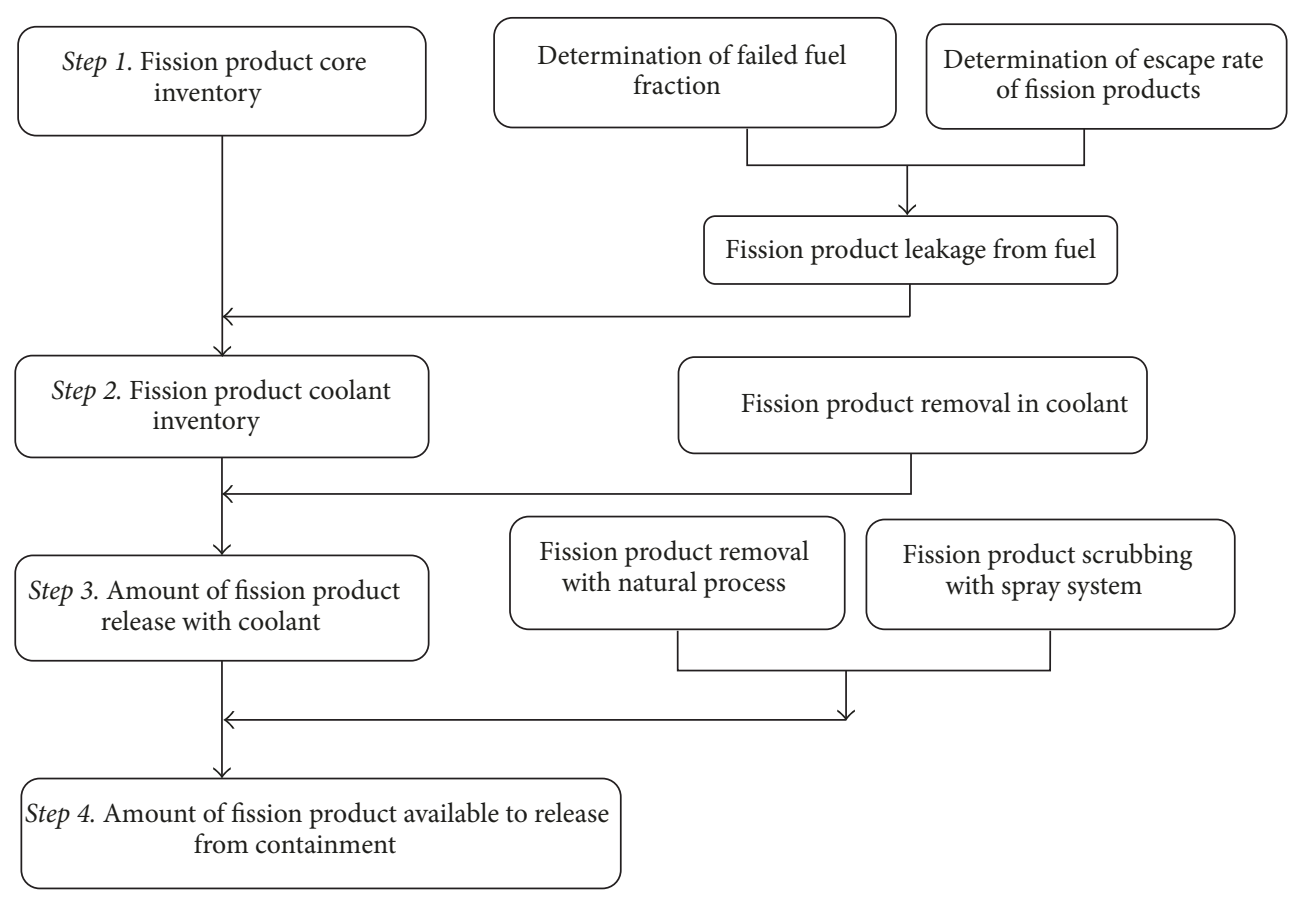

FIGURE 4: Flow chart of in-containment fission product source term estimation.

fission product behavior and spray system effect on the incontainment source term. The generated computer code uses the ORIGEN2.2 core inventory which has been evaluated for one complete fuel cycle. The computer-generated program contains two nested functions, one contains coupled ODEs and 2 nd is the implementation of Runge-Kutta 4th-order method (Figures 5 and 6). The program loads the input file and reads the input parameters and conditions of containment spray parameters (temperature, pressure, Reynolds number, Schmidt number, etc.) in the main program. The main program calls the nested subfunction "ODERK4" to solve the ODEs. "ODERK4" calls another subnested function "diffeq" which contains the coupled ODEs. The computergenerated program has two nested subprograms and 4 loops. The outermost loop controlled the droplets and spray system conditions. There are five parallel nested loops that solve the slopes $K 1, K 2, K 3$, and $K 4$ (Figures 5 and 6) and solution of ODEs at time step $t$.

The time step is controlled by the 2 nd loop. The 2 nd loop computes the $i$ th fission product for all the time intervals. When loop 2 is terminated then next fission product is called. The program loads the parameters of next fission product and computes its activity. The number of fission products is controlled by the third loop. Then the third loop is terminated. The program asks for the change in droplet parameters. If the condition is true, then the program calculates the droplet conditions and repeats the entire process through repeated nested loops. The condition of a spray system for its activation and deactivation is checked at each time step when the program reads subfunction ODE. The flow chart 


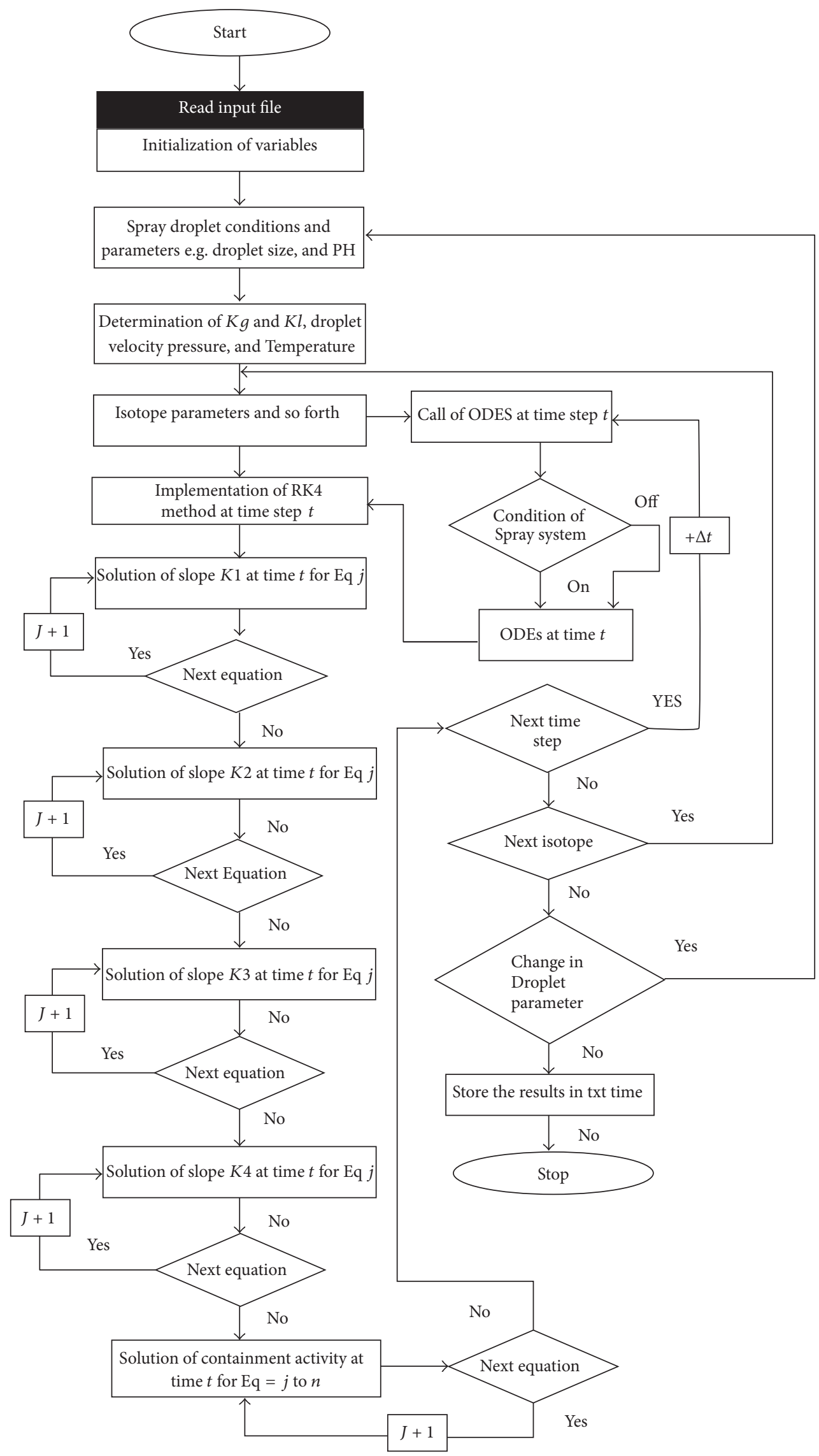

FIGURE 5: Flow diagram of a computer program. 


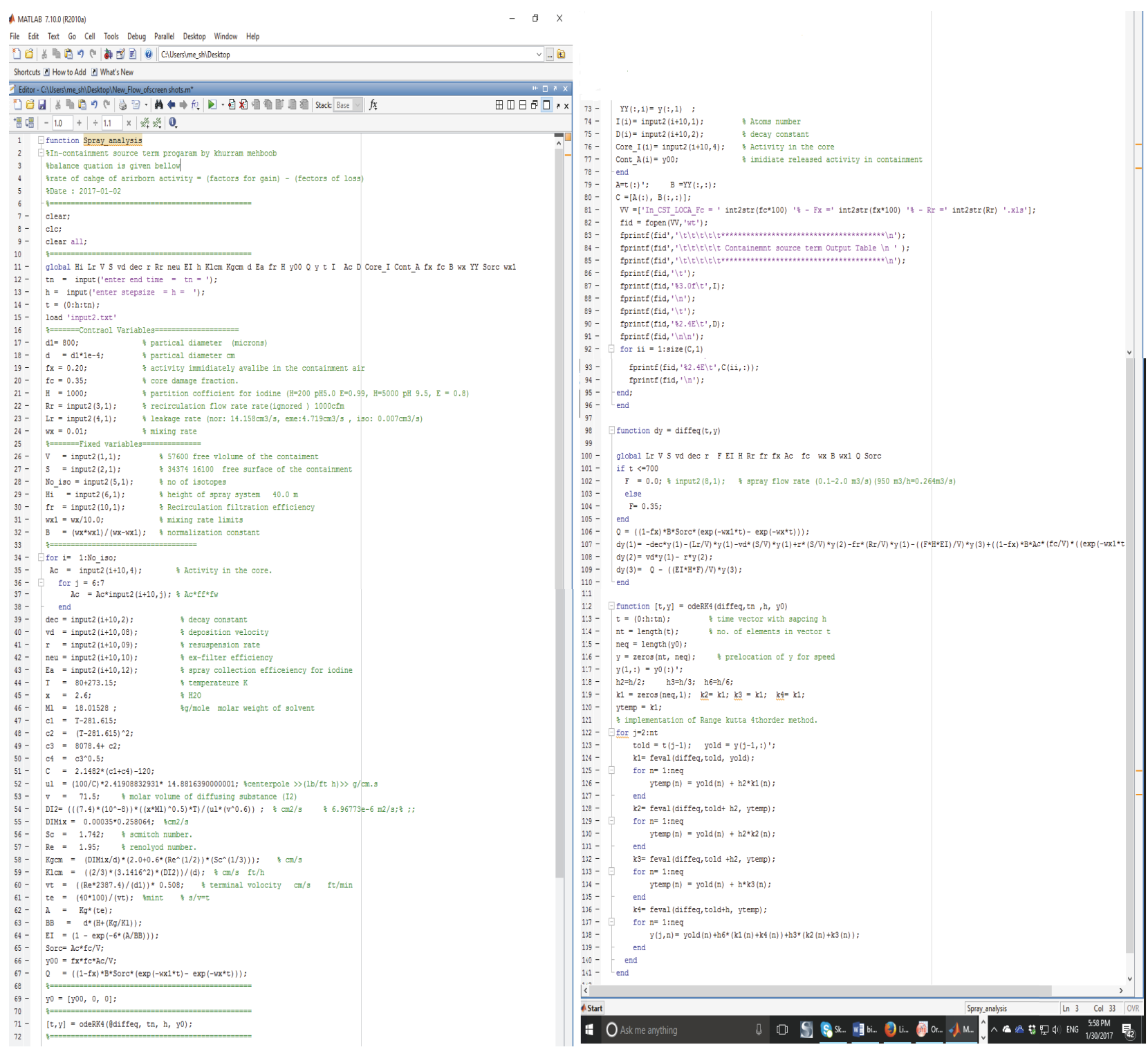

FIGURE 6: Screenshot of the computer code.

of the computer-generated program is depicted in Figure 5 and screenshot of the program implementation is depicted in Figure 6.

\section{Simulation Results and Discussion}

5.1. Volumetric Mass Inventory. The generation of fission isotope mass is proportional to the fuel temperature, fuel type, accident condition, reactor type, and reactor operation time [7]. The noble gases are hazardous because they deliver the external and inhaled dose as well as the whole-body dose. Iodine is more hazardous because it delivers the thyroid dose, while the other isotopes contribute in the whole-body and lungs dose. We have selected the isotopes based on their health hazards and half-lives. The selected radioactive isotopes inventory evaluated by ORIGEN2.2 code has been compared with literature (i.e., [29]). A good agreement has been seen between calculated inventory and literature inventory (Figure 7).

The comparison of core and coolant inventory with AP1000 and KORI-1 is listed in Table 5. The core and coolant inventory have been found to be comparable with AP-1000 PWR [42]. Since our plant and AP-1000 have similar core power whereas KORI-1 is $1600 \mathrm{MWth}$ PWR, the core and coolant inventories for selected isotopes for KORI-1 have been found to be less in quantity as compared to our plant and AP-1000. An acceptable comparison has been found for core inventories. However, the coolant inventory for AP-1000 has been found to be a bit higher. This may be because of core design and a higher fuel concentration in AP-1000. The 


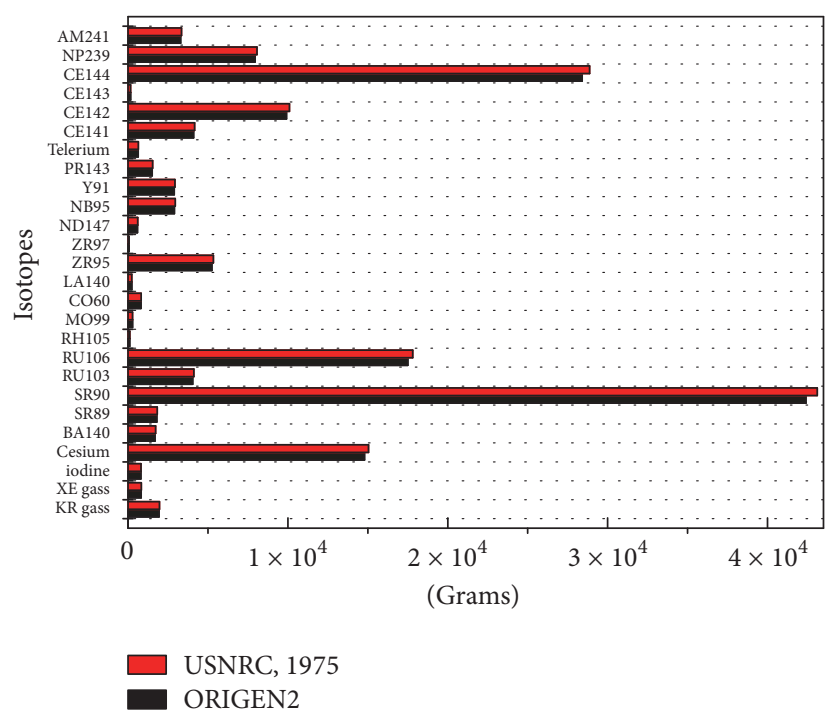

Figure 7: Selected isotope mass inventory for one complete fuel cycle of 1000 MWe conventional PWR.

coolant inventory has been evaluated with $0.25 \%$ fail fuel fraction. The noble gases and iodine are found in significant quantity. However, ${ }^{90} \mathrm{Sr},{ }^{103} \mathrm{Ru},{ }^{106} \mathrm{Ru}$, and ${ }^{144} \mathrm{Ce}$ are found to be in dominant. The radioisotopes volumetric mass release during in-vessel release phase has been simulated for the accident condition listed in Tables 3 and 4 .

The volumetric radioactive material inventory for selected isotopes inside the containment building is depicted in Figure 8. The volumetric activity inside the reactor building first increased and then started decreasing. This is because of competition between removal rate and fission product generation rate into the containment atmosphere. The volumetric radioactive mass was found to increase during first 300 seconds and then started decreasing at a constant rate. The cesium mass was found to be dominant with 100 times higher than the other radioactive masses. The krypton gas is found to be $15 \%$ higher in magnitude with xenon gas. However, the other isotopes showed similar behavior but with less magnitude. 35\% core damage has been considered and the puff release of fission products has been considered as $20 \%\left(f_{x}\right)$, whereas the rest of radioisotopes were released along with coolant with mixing rate $w_{x}=0.01 \mathrm{~s}^{-1}$. The exhaust rate is assumed to be $L r=14.15 \mathrm{~m}^{3} / \mathrm{s}$ and recirculation filtration of purging and cleaning system $\mathrm{Rr}=4.175 \mathrm{~m}^{3} / \mathrm{s}$.

5.2. Spray System Effect. In this research, we have studied the effect of the spray system in mitigating the radioactive masses (gaseous and particles) released during in-vessel release phase. The effect of the spray system has been studied by activating the containment spray system at different time after the break. The simulation has been carried out by assuming the containment temperature at $80^{\circ} \mathrm{C}$ and pressure of $0.514 \mathrm{MPa}$ with $\mathrm{pH} 5.0$ and $\mathrm{pH} 9.5$ and with alkaline spray solution. The spray system was found to have minimum effect on noble gases, whereas effective mitigation of iodine and other radioactive particles has been seen (Figure 9). The spray system is started at $100 \mathrm{~s}, 500 \mathrm{~s}, 1000 \mathrm{~s}$, and $1500 \mathrm{~s}$ after the release time. The effect of spray system activation time on noble gases and iodine is shown in Figure 9.

It has been seen that the airborne radioactive iodine starts reducing with the activation of the spray system. The airborne iodine was first found to increase and then decreased exponentially when the containment spray system was active at $100 \mathrm{~s}$ and $500 \mathrm{~s}$. This is because of competition between the continuous source of radioactive iodine $(\mathrm{Pi})$ coming from reactor pressure vessel (RPV) and removal of iodine with the spray system (Figure 9). A rapid decrease in iodine inventory has been seen with the activation of the spray system at the time greater than $500 \mathrm{~s}$ (Figure 9). The iodine concentration reduced exponentially with the activation of the spray system. The droplet size has been assumed as $800 \mu \mathrm{m}$ for the simulation. A similar effect has been observed with cesium when the spray system is activated at $100 \mathrm{~s}, 500 \mathrm{~s}, 1000 \mathrm{~s}$, and $1500 \mathrm{~s}$ with flow rate of $0.35 \mathrm{~m}^{3} / \mathrm{s}$. The concentration of cesium mass showed an exponential increase and then started decreasing eventually with the activation of the spray system. It has been observed that the cesium remains relatively the same in concentration when the spray system is activated at $100 \mathrm{~s}$ and $500 \mathrm{~s}$. However, a rapid decrease in cesium has been seen when the spray system is active after $500 \mathrm{~s}$ (Figure 10).

However, when the simulation has been carried out for barium and strontium, it has been observed that the particulate barium and strontium reduced to their minimum value within $2500 \mathrm{~s}$ after the accident with activation of the spray system. The response of barium and strontium is depicted in Figure 11. In contrast to cesium, the response of barium and strontium to the spray system has been found to be similar to the iodine, but an insignificant difference has been observed for barium and strontium with the activation of the spray system at $100 \mathrm{~s}$ and $500 \mathrm{~s}$ (Figure 11). Moreover, barium and strontium have been found to be similar in magnitude and behavior.

During LB-LOCA, the temperature and pressure inside the containment start rising. The temperature and pressure reached $80^{\circ} \mathrm{C}$ and $0.154 \mathrm{MPa}$, respectively, within few minutes. To determine the thresholds for spray activations to control the rising pressure and temperature inside the containment, we have simulated the failure time of spray system and have analyzed the effect on airborne iodine. The response of airborne iodine to the spray system failure is depicted in Figure 12. Figure 12 indicates that the early failure of the system $(t=100 \mathrm{~s})$ does not affect the airborne iodine concentration. The slight decrease in airborne iodine concentration is seen if the spray system is failed at $500 \mathrm{~s}$. However, if the spray system is operated for a longer period, for example, $1000 \mathrm{~s}$ to $1500 \mathrm{~s}$ during the in-vessel phase, the airborne concentration of iodine is reduced significantly. The failure of the system at $1000 \mathrm{~s}$ and $1500 \mathrm{~s}$ caused the regaining of airborne iodine (Figure 12). We have simulated the effect of spray system failure by assuming that the spray system is activated with the break $(t=0 \mathrm{~s})$.

Furthermore, the collection efficiency of spray also depends on the containment atmospheric temperature, pressure, and spray water $\mathrm{pH}$ value. We have also simulated the 


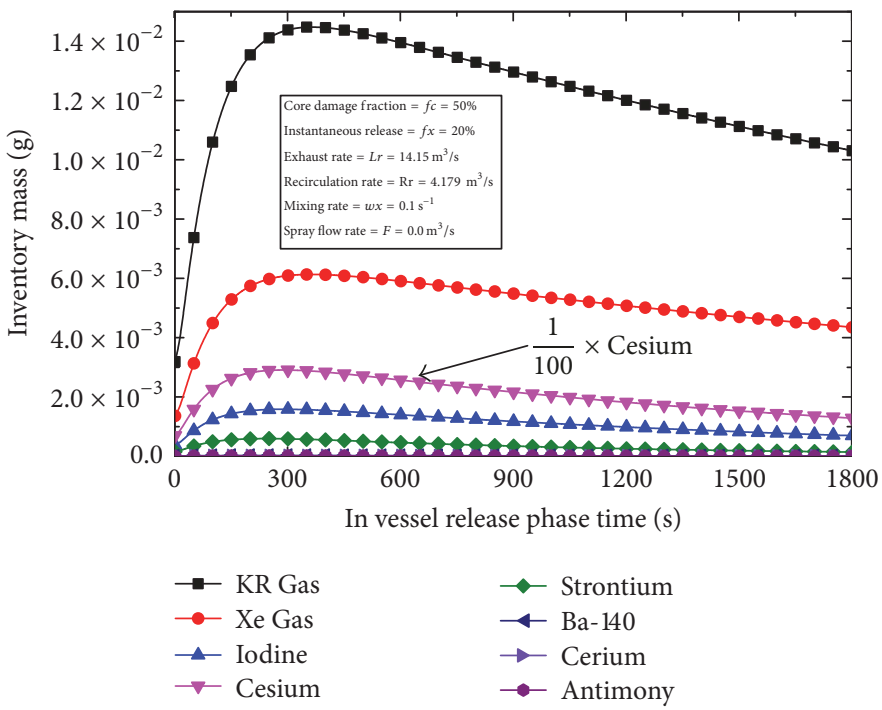

FIGURE 8: Radionuclide mass inventory during in-vessel release phase with mixing rate $w_{x}=0.1 \mathrm{~s}^{-1}$.

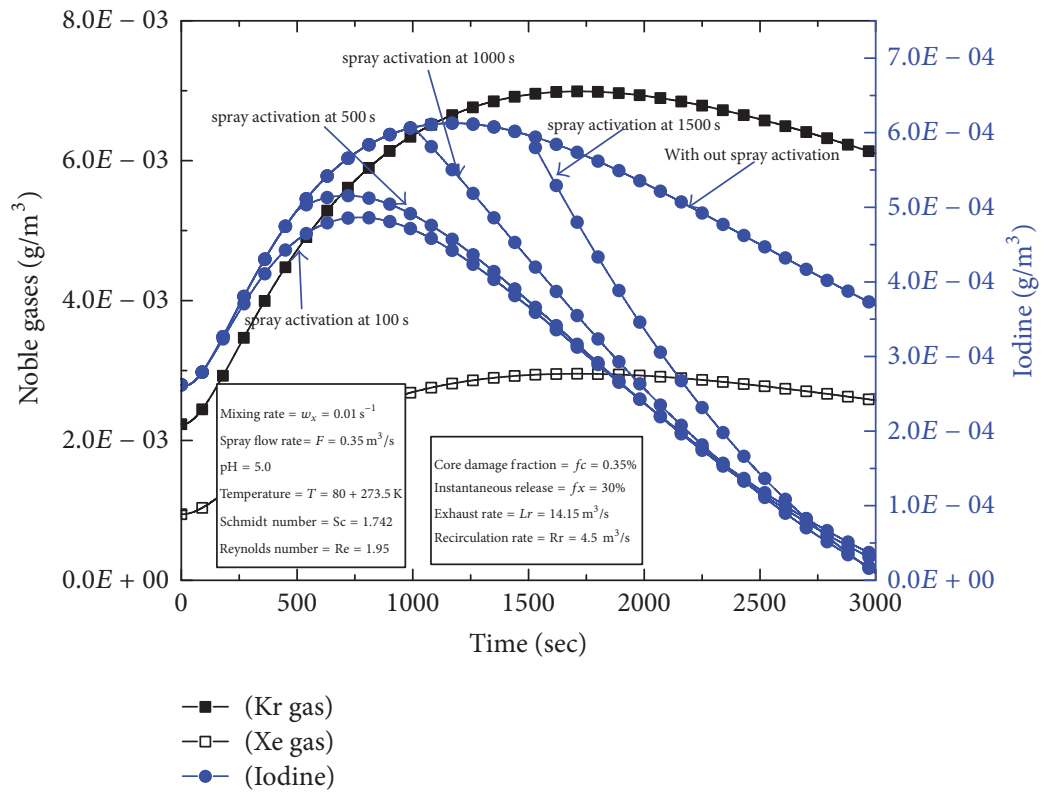

FIGURE 9: Noble gases and iodine inventory during in-vessel release phase with mixing rate $w_{x}=0.01 \mathrm{~s}^{-1}$.

effect of spray system for different $\mathrm{pH}$ values and spray with an alkaline solution. The results are depicted in Figure 13. We have chosen $700 \mathrm{~s}$ to activate the spray systems with different $\mathrm{pH}$ values. The results show that the higher $\mathrm{pH}$ spray solution ( $\mathrm{pH} 9.5)$ and alkaline solution $\left(\mathrm{Na}_{2} \mathrm{~S}_{2} \mathrm{O}_{3}\right)$ have similar scrubbing rate. However, insignificant removal of iodine has been seen with the spray solution of lower $\mathrm{pH}$ value. Therefore, results of different $\mathrm{pH}$ values and alkaline spray solution indicated that the higher $\mathrm{pH}$ solution and alkaline solution have similar removal characteristics for iodine. The iodine removal rates of boric $(\mathrm{pH} 5.0), \mathrm{NaOH}$ ( $\mathrm{pH}$ 9.5), and alkaline solution with different droplet sizes are shown in Figure 14. It has been seen that spray water with higher $\mathrm{pH}$ value and alkaline spray solution have similar iodine removal rates. This is because the partition coefficient of solvent is much higher for the spray with $\mathrm{pH}$ 9.5, whereas the alkaline spray may have higher reaction rate with gaseous iodine. However, for the spray solutions with $\mathrm{pH}$ value 5.0, the removal rate decreases in approximation to $1 / d$, whereas for higher $\mathrm{pH}$ and alkaline solution, removal rate approximates to $1 / d^{2}$ for iodine (Figure 15 ).

The in-containment volumetric mass concentration is simulated for spray droplet sizes $(100 \mu \mathrm{m}-1000 \mu \mathrm{m})$ under the atmospheric conditions with a temperature and pressure of $80^{\circ} \mathrm{C}$ and $0.154 \mathrm{MPa}$, respectively, by assuming $35 \%$ core damage and $20 \%$ burst release. The rest of masses are assumed to be released along with the coolant with mixing rate $w_{x}=$ $0.01 \mathrm{~s}^{-1}$. The containment exhaust $\mathrm{Lr}$ is kept $14.15 \mathrm{~m}^{3} / \mathrm{s}$ and 


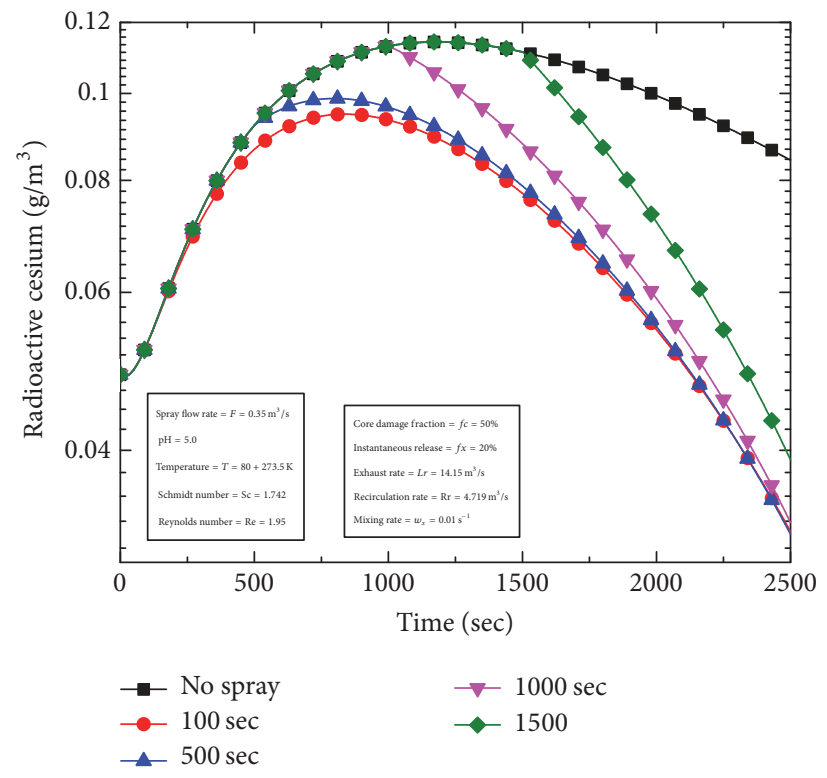

FIGURE 10: Cesium mass inventory with different spray activation time during in-vessel release phase with mixing rate $w_{x}=0.01 \mathrm{~s}^{-1}$.

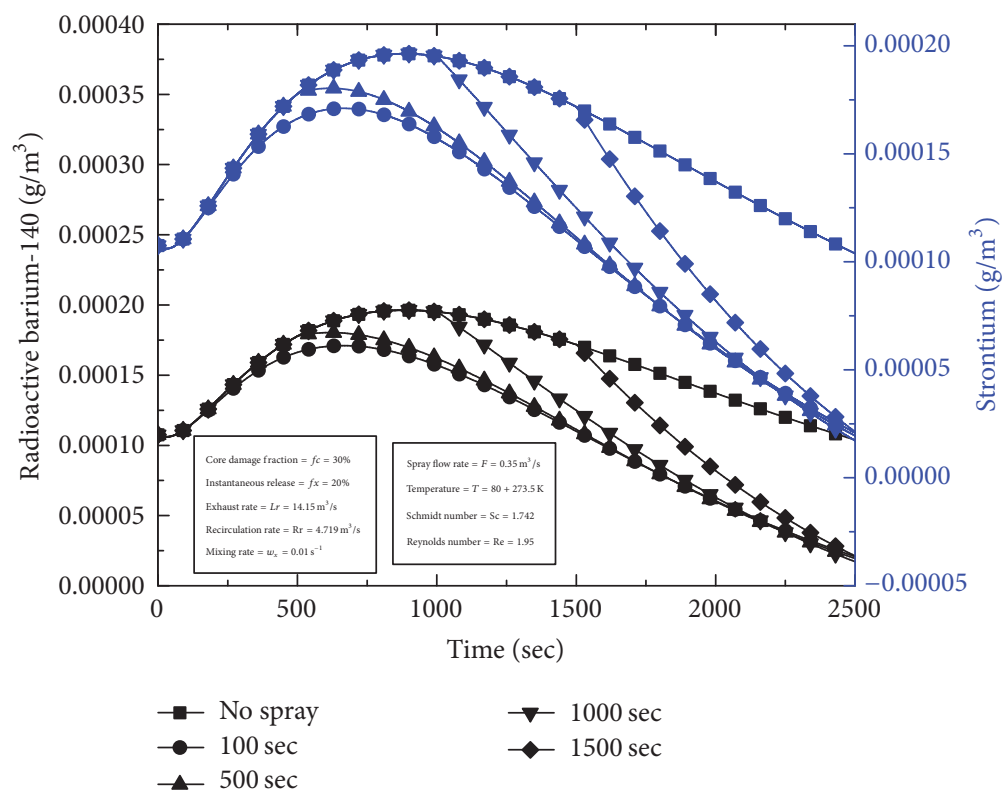

FIGURE 11: Response of airborne barium and strontium with spray activation time during in-vessel release phase with mixing rate $w_{x}=0.01 \mathrm{~s}^{-1}$.

air recirculation filters are supposed to be terminated $(\mathrm{Rr}=$ $0.0 \mathrm{~m}^{3} / \mathrm{s}$ ). The containment spray system is activated with the initiation of an accident with a constant flow rate of $0.2 \mathrm{~m}^{3} / \mathrm{s}$. The simulation results showed that the droplet size is quite effective in reducing the airborne fission products. It has been observed that the concentration of airborne radioactive concentration decreases with a decrease in droplet size (Figure 15). The peak concentration of tellurium mass reaches a maximum concentration at a longer time with the higher droplet diameter. The magnitude of maximum concentration has been found to be approximately equal to the inverse of droplet diameter $(1 / d)$. The maximum removal rate for iodine has been found to be $452 \mathrm{~s}^{-1}$ with alkaline solution spray with droplet size of $100 \mu \mathrm{m}$. The removal rate was found to decrease exponentially as the droplet diameter increased (Figure 14).

The large droplets have less interaction with isotopes due to less resident time in air, which results in decrease in efficiency. The removal rate of iodine for $\mathrm{pH} 9.5$ and an alkaline solution has been found to be $44.7 \mathrm{~s}^{-1}$ with the droplet size of $1000 \mu \mathrm{m}$. The gas phase and liquid phase coefficients play a significant role in absorption efficiency. Both gas and liquid phases mass transfer coefficients $\left(K_{G}\right.$ and $K_{L}$ ) decrease drastically with an increase in droplet size 


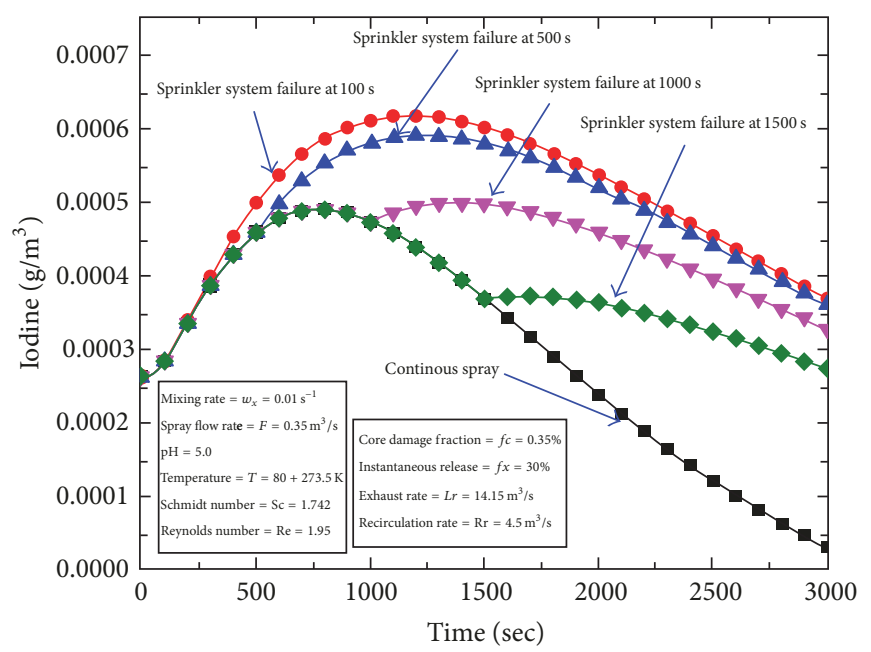

FIGURE 12: Radioactive iodine with containment spray system failures during in-vessel release phase with mixing rate $w_{x}=0.01 \mathrm{~s}^{-1}$.

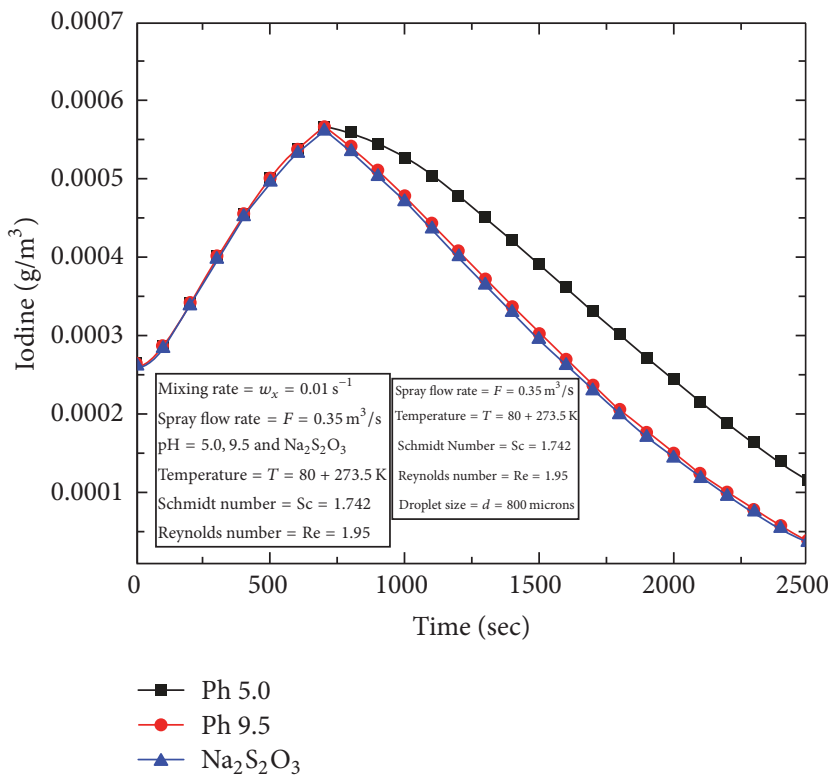

FIGURE 13: Response of radioactive iodine for spray $\mathrm{pH}$ value during in-vessel release phase with mixing rate $w_{x}=0.01 \mathrm{~s}^{-1}$.

(Figure 16). An insignificant change in gas phase $\left(K_{G}\right)$ and liquid phase $\left(K_{L}\right)$ mass transfer coefficient has been observed for the droplet of $450 \mu \mathrm{m}$ to $850 \mu \mathrm{m}$ (Figure 16). Moreover, the minuscule difference in the removal rate of iodine has been observed for $450 \mu \mathrm{m}$ to $850 \mu \mathrm{m}$ droplet size (Figure 14). In this work, the effective droplet size for the removal of volumetric radioactive mass has been observed to be $450 \mu \mathrm{m}$ to $850 \mu \mathrm{m}$ (Figure 15). Therefore, keeping in view the acceptance criteria for spray system operation described in NUREG-800, we can suggest that droplet size should be between $450 \mu \mathrm{m}$ and $850 \mu \mathrm{m}$ for the static atmospheric conditions described in this work. However, the gas and liquid phase mass transfer coefficients $\left(K_{G}\right.$ and $\left.K_{L}\right)$ are also related to the inverse square of droplet diameter $\left(1 / d^{2}\right)$.

Moreover, the validation of our model has been carried out with the experimental data form TOSQAN results [43].
The removal rate for $0.9 \mu \mathrm{m}$ to $1.3 \mu \mathrm{m}$ aerosols has been measured between $0.0001 \mathrm{~s}^{-1}$ and $0.0004 \mathrm{~s}^{-1}$ in TOSQAN vessel by Porcheron et al. (2010) [43], whereas the removal rate calculated by our model for $1.0 \mu \mathrm{m}$ aerosol size with spray flow rate of $0.35 \mathrm{~m}^{3} / \mathrm{s}$ is $0.00025 \mathrm{~s}^{-1}$, which is found to be acceptable (Figure 17(a)). Since TOSQAN experiment has been performed in a homogeneous spray condition, we have compared the normalized removal of aerosol with TOSQAN experiment. A small difference in removal is due to the different droplet sizes and flow rate. Moreover, Porcheron et al's (2010) experiment has been performed on TOSQAN vessel, which is almost 10 times smaller in size than our vessel used for our model. Overall, a similar behavior of removal has been seen (Figure 17(b)), which is found to be acceptable and comparable. However, the removal rate from TOSQAN vessel experiment is relatively close to our simulated results. 


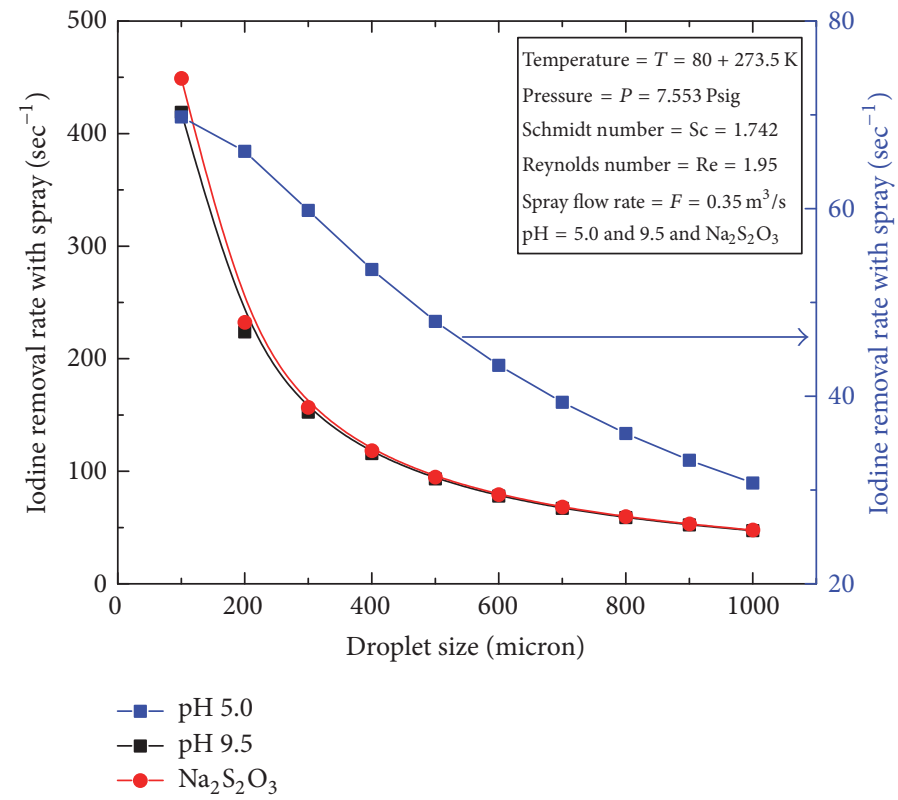

FIGURE 14: Droplet removal rate for iodine at $\mathrm{pH} 5.0$ and 9.5 and with alkaline spray solution $\left(\mathrm{Na}_{2} \mathrm{~S}_{2} \mathrm{O}_{3}\right)$.

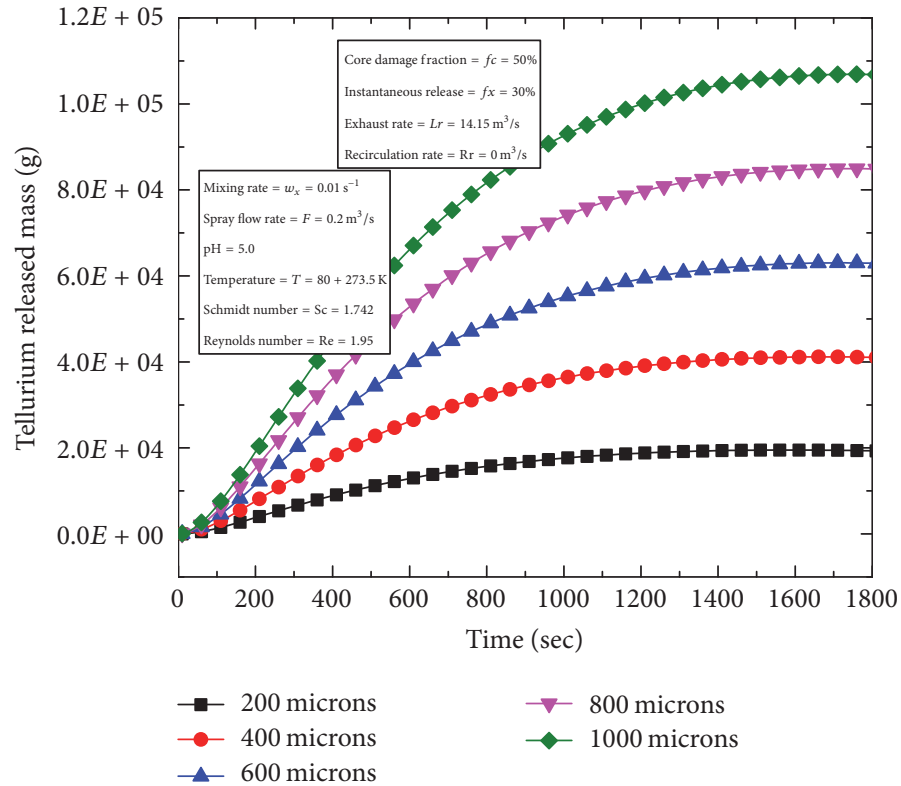

FIGURE 15: Radioactive tellurium mass released during in-vessel release phase with mixing rate $w_{x}=0.01 \mathrm{~s}^{-1}$.

Therefore, we can say it is comparable because the normalized removal trends are similar (Figure 17(b)).

\section{Summary}

In this work, a kinetic simulation study of volumetric radioisotope mass inventory released inside the containment building has been carried out. The modeling and simulation have been carried out in MATLAB to simulate the radioisotope mass inventory within the containment under loss of the coolant accident (LOCA). The fission product inventory calculation has been evaluated with ORIGEN2.2 code. The simulation constraints used in this work are listed in Tables 3 and 4.

The inventory of 1000 MWe PWR is evaluated by ORIGEN2.2 code and compared with the core inventory listed in the USNRC (1975) (Figure 7) and with AP-1000 core inventory [42]. A good comparison has been seen with inventories listed in literature (Figure 7) but the coolant inventory of AP-1000 has been found to be slightly higher than our selected plant (Table 5). The difference might be because we have calculated the coolant inventory with $0.25 \%$ fail fuel fraction (Table 5). From simulation outcomes, it has been noticed that the in-containment concentration of noble 


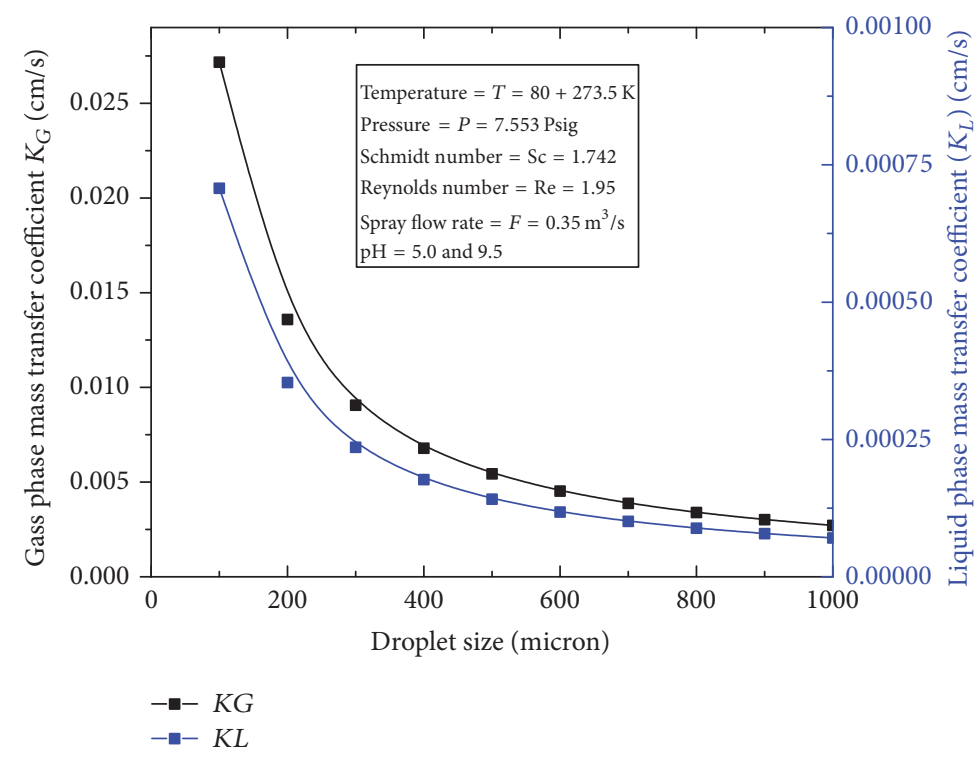

Figure 16: A comparison of gas phase mass transfer coefficient $\left(K_{G}\right)$ and liquid phase mass transfer coefficients $\left(K_{L}\right)$ for elemental iodine constant $\mathrm{pH}=5.0$ and $T=80^{\circ} \mathrm{C}$.

gases, iodine, cesium, tellurium, cerium, and so forth first increases and then decreases exponentially or linearly after reaching the maximum concentration. The cesium was found to be dominant among all groups due to its high inventory.

The prime safety and mitigating equipment to relegate the airborne radioisotopes is the in-containment spray system. The droplet diameter has an effective role in airborne fission product scrubbing. There is a higher tendency of interaction of airborne particles (Figures 14 and 15) with smaller droplet size due to their higher values of liquid and phase mass transfer coefficients $\left(K_{L}\right.$ and $K G$ ) (Figure 16). The iodine removal rate increases with smaller droplet's diameters (Figure 16). This may be because droplet has longer exposure time in the air. Also, the liquid and gas phase mass transfer coefficients $\left(K_{L}, K_{G}\right)$ are inversely proportional to the square of droplet diameter. The removal rate for iodine has been found to be analogous to a spray with pH 9.5 and alkaline spray (sodium thiosulfate). It has been seen that spray water with higher $\mathrm{pH}$ value and alkaline spray solution have similar iodine removal rates. It may be because the partition coefficient of solvent in a droplet with $\mathrm{pH} 9.5$ is much higher, which results in higher removal of iodine, whereas the alkaline spray may have higher reaction rate with iodine gas. A higher removal rate has been observed with greater $\mathrm{pH}$ value (Figure 14) and smaller droplet size (Figure 15). Therefore, keeping in view the acceptance criteria of spray system mentioned in NUREGCR0800 [44], we suggest that the droplet diameter should be between $450 \mu \mathrm{m}$ and $850 \mu \mathrm{m}$, with $\mathrm{pH}$ value higher than 9.0. If the containment spray system has been operated along with the initiation of leakage of fission products, the airborne concentration of fission products will be minimum (Figures 9,10 , and 11). However, the delay operation caused the higher airborne concentration of radioactive mass. Regaining in airborne radioactive mass concentration has been observed if the containment spray system fails during in-vessel release phase (Figure 12). Moreover, the removal rate and normalized in-vessel concentration of aerosols are comparable with TOSQAN experimental data, which is found to be in good agreement and acceptable (Figures 17(a) and 17(b)).

Overall, from reactor safety point of view and from simulation outcomes, we can conclude that the airborne concentration of radioisotopes reduces significantly with the spray system. The spray system plays a vital role in reductions of airborne radioactive concentration inside the containment. Currently, containment spray system with a mean droplet diameter of $1000 \mu \mathrm{m}$ to $1200 \mu \mathrm{m}$ is installed in several NPPs. Based on our work, we can suggest that $450 \mu \mathrm{m}$ to $850 \mu \mathrm{m}$ mean droplet diameter of containment spray system should be used to get maximum radiation hazard's safety. Moreover, from our results, we can conclude that the spray system should be operated within $500 \mathrm{~s}$ after the accident and should be operated for more than $3000 \mathrm{~s}$ (whole in-vessel release phase). The uncertainties in our simulated results depend upon the uncertainties' available data in the literature.

\section{Nomenclature}

$\begin{array}{ll}S: & \text { Surface area }\left(\mathrm{m}^{2}\right) \\ u_{t}: & \text { Terminal deposition velocity }(\mathrm{m} / \mathrm{s}) \\ V: & \text { Containment volume }\left(\mathrm{m}^{3}\right) \\ F: & \text { Spray flow rate }\left(\mathrm{m}^{3} / \mathrm{s}\right) \\ E_{i}: & \text { Collection efficiency }(\%) \\ H: & \text { Partition coefficient }(\#) \\ R_{\text {res }}: & \text { Air recirculation rate }\left(\mathrm{m}^{3} / \mathrm{s}\right) \\ L_{r}: & \text { Exhaust leakage rate }\left(\mathrm{m}^{3} / \mathrm{s}\right) \\ r: & \text { Resuspension rate }\left(\mathrm{s}^{-1}\right) \\ P_{i}(t): & \text { Source term }\left(\mathrm{g} / \mathrm{m}^{3}\right) \\ m_{v}(t): & \text { Volumetric mass of } \mathrm{radioisotopes}\left(\mathrm{g} / \mathrm{m}^{3}\right) \\ d: & \text { Droplet diameter }(\mu \mathrm{m}) \\ m_{s}: & \text { Surface activity }\left(\mathrm{g} / \mathrm{m}^{2}\right)\end{array}$




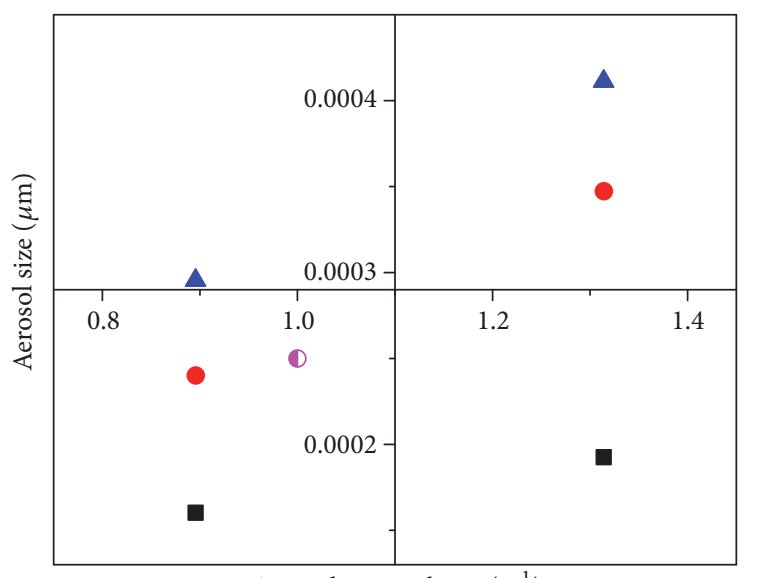

Aerosol removal rate $\left(\mathrm{s}^{-1}\right)$

- 700 s, Porcheron et al. (2010)

1100 s, Porcheron et al. (2010)

- 300 s, Porcheron et al. (2010)

- This work's removal rate

(a)

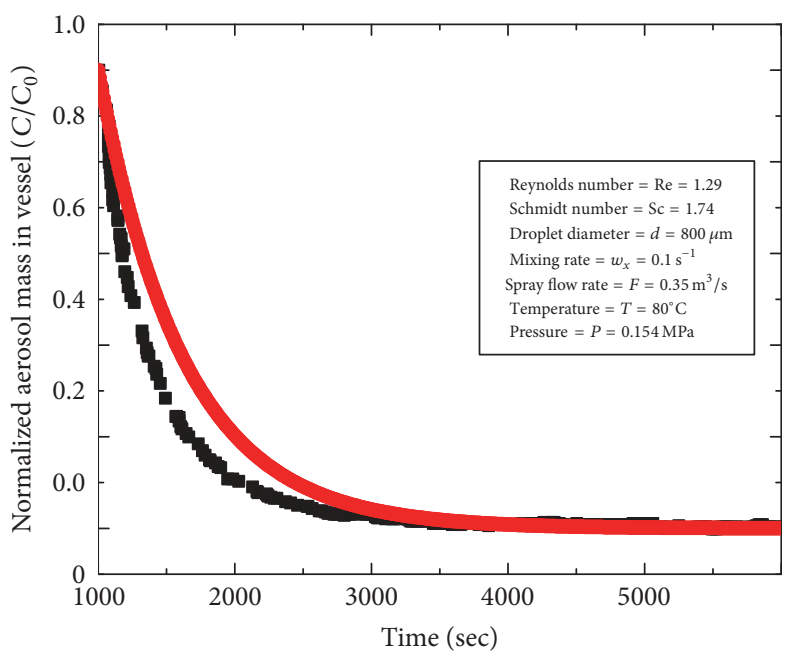

TOSQAN, Porcheron et al. (2010)

- Our model

(b)

FIGURE 17: A comparison of removal rate (a) and normalized aerosol mass (b) with TOSQAN experiment.

$t_{d}$ : Droplet resident time in containment air

(s)

$K_{G}:$ Gas phase mass transfer coefficient $(\mathrm{cm} / \mathrm{s})$

$K_{L}$ : Liquid phase mass transfer coefficient $(\mathrm{cm} / \mathrm{s})$

Sc: Schmidt number (\#)

$D_{L}$ : Iodine diffusion coefficient in droplet vapors $\left(\mathrm{cm}^{2} / \mathrm{s}\right)$

$K_{L}$ : Liquid phase mass transfer coefficient $(\mathrm{cm} / \mathrm{s})$

Re: Reynolds number (\#)

$M_{l}$ : Molar weight of solvent ( $\mathrm{g} / \mathrm{mole}$ )
$T$ : Temperature $(\mathrm{K})$

$x$ : Degree of solvent (\#)

$B$ : Normalization constant.

Greek Symbols

$\lambda$ : Decay constant $\left(\mathrm{s}^{-1}\right)$

$v$ : Molecular volume of diffusing elemental

iodine $\left(\mathrm{cm}^{3} / \mathrm{g}\right)$

$\eta_{r c}:$ Filters efficiency (\%)

$\mu_{l}$ : Viscosity $\left(\mathrm{g} \cdot \mathrm{s}^{-1} \cdot \mathrm{m}^{-1}\right)$.

Subscripts

$i$ : Isotope number.

Abbreviations

PWR: Pressurized water reactor

FP: $\quad$ Fission products

VVER: Vodo-Vodyanoi Energetichesky Reactor

PASSAM: Passive and active system on severe accident source term mitigation

LWR: Light water reactor

NPP: $\quad$ Nuclear power plant

IPHWR: Indian Pressurized Heavy Water Reactor.

\section{Conflicts of Interest}

The author declares that there are no conflicts of interest.

\section{Acknowledgments}

This article was funded by the Deanship of Scientific Research (DSR) at King Abdulaziz University, Jeddah. The author, therefore, acknowledges with thanks DSR for technical and financial support.

\section{References}

[1] M. Dehjourian, M. Rahgoshay, R. Sayareh, G. Jahanfarnia, and A. S. Shirani, "Effect of Spray System on Fission Product Distribution in Containment During a Severe Accident in a Two-Loop Pressurized Water Reactor," Nuclear Engineering and Technology, vol. 48, no. 4, pp. 975-981, 2016.

[2] J. Malet and X. Huang, "Influence of spray characteristics on local light gas mixing in nuclear containment reactor applications," Computers \& Fluids, vol. 107, pp. 11-24, 2015.

[3] J. Malet, Z. Parduba, S. Mimouni, and J. Travis, "Achievements of spray activities in nuclear reactor containments during the last decade," Annals of Nuclear Energy, vol. 74, no. C, pp. 134142, 2014

[4] F. C. Rahim, M. Rahgoshay, and S. K. Mousavian, "A study of large break LOCA in the AP1000 reactor containment," Progress in Nuclear Energy, vol. 54, no. 1, pp. 132-137, 2012.

[5] F. C. Iglesias, B. J. Lewis, P. J. Reid, and P. Elder, "Fission product release mechanisms during reactor accident conditions," Journal of Nuclear Materials, vol. 270, no. 1, pp. 21-38, 1999. 
[6] A. Tigeras, M. Bachet, H. Catalette, and E. Simoni, "PWR iodine speciation and behaviour under normal primary coolant conditions: An analysis of thermodynamic calculations, sensibility evaluations and NPP feedback," Progress in Nuclear Energy, vol. 53, no. 5, pp. 504-515, 2011.

[7] K. Mehboob and C. Xinrong, "Source term evaluation of two loop PWR under hypothetical severe accidents," Annals of Nuclear Energy, vol. 50, pp. 271-284, 2012.

[8] State of Art Report (SOAR), "On Containment Thermalhydraulics and Hydrogen Distribution," CSNI/R(99)-16, State of Art, 1999.

[9] J. Malet, "Presentation of the tests matrix for the TOSQAN facility Spray Programme," IRSN technical report, DSU/SERAC/ LPMAC/03-06, 2003.

[10] J. Malet, P. Lemaitre, E. Porcheron et al., Benchmarking of CFD and LP codes for spray systems in containment applications: spray tests at two different scales in the TOSQAN and MISTRA facilities, CFD4NRS, 2006.

[11] A. Filippov, S. Grigoryev, N. Drobyshevsky, A. Kiselev, A. Shyukin, and T. Yudina, "CMFD simulation of ERCOSAM PANDA spray tests PE1 and PE2," Nuclear Engineering and Design, vol. 299, pp. 81-94, 2016.

[12] S. Mimouni, J.-S. Lamy, J. Lavieville, S. Guieu, and M. Martin, "Modelling of sprays in containment applications with A CMFD code," Nuclear Engineering and Design, vol. 240, no. 9, pp. 2260$2270,2010$.

[13] A. del Corno, S. Morandi, F. Parozzi, L. Araneo, and F. Casella, "Experiments on aerosol removal by high-pressure water spray," Nuclear Engineering and Design, vol. 311, pp. 28-34, 2017.

[14] E. Porcheron, P. Lemaitre, A. Nuboer, V. Rochas, and J. Vendel, "Experimental investigation in the TOSQAN facility of heat and mass transfers in a spray for containment application," Nuclear Engineering and Design, vol. 237, no. 15-17, pp. 1862-1871, 2007.

[15] T. Haste, F. Payot, C. Manenc et al., "Phébus FPT3: Overview of main results concerning the behaviour of fission products and structural materials in the containment," Nuclear Engineering and Design, vol. 261, pp. 333-345, 2013.

[16] L. E. Herranz and B. Clément, "In-containment source term: Key insights gained from a comparison between the PHEBUSFP programme and the US-NRC NUREG-1465 revised source term," Progress in Nuclear Energy, vol. 52, no. 5, pp. 481-486, 2010.

[17] N. Girault, L. Bosland, S. Dickinson et al., "LWR severe accident simulation: Iodine behaviour in FPT2 experiment and advances on containment iodine chemistry," Nuclear Engineering and Design, vol. 243, pp. 371-392, 2012.

[18] H. Anglart, F. Alavyoon, and R. Novarini, "Study of spray cooling of a pressure vessel head of a boiling water reactor," Nuclear Engineering and Design, vol. 240, no. 2, pp. 252-257, 2010.

[19] M. Jain, B. John, K. N. Iyer, and S. V. Prabhu, "Characterization of the full cone pressure swirl spray nozzles for the nuclear reactor containment spray system," Nuclear Engineering and Design, vol. 273, pp. 131-142, 2014.

[20] L. S. Lebel, M. H. Piro, R. Maccoy, A. Clouthier, and Y.S. Chin, "Concept for a cyclonic spray scrubber as a fission product removal system for filtered containment venting," Nuclear Engineering and Design, vol. 297, pp. 60-71, 2016.

[21] K. Mehboob and M. S. Aljohani, "Effect of Spray System on in Containment Fission Product Washout During In-Vessel Release Phase," in Proceedings of the 2017 25th International
Conference on Nuclear Engineering, p. V002T03A005, Shanghai, China.

[22] N. Karl-Heinz, The Radiochemistry of Nuclear Power Plants with Light Water Reactors, Walter de Gruyter Berlin, New York, NY, USA, 1st edition, 1997.

[23] Lechler inc, "Spray Nozzles for Nuclear Power Generation," 2017, http://www.lechler.de/is-bin/intershop.static/WFS/ LechlerDE-Shop-Site/LechlerDE-Shop/en_IN/PDF/05_service_ support/industrie/broschueren/englisch/lechler_brochure_nuclear_power_GB_0314.pdf.

[24] A. M. Bukrinsky, Y. V. Rzheznikov, Y. V. Shvyryaev et al., "Accident Localization System under LB LOCA conditions at NPP with VVER-440," Applied Thermal Engineering, vol. 4, pp. 47-49, 1978.

[25] V. N. Blinkov, O. I. Melikhov, V. I. Melikhov, M. V. Davydov, H. Wolff, and S. Arndt, "Experimental Studies for the VVER440/213 Bubble Condenser System for Kola NPP at the Integral Test Facility BC V-213," Science and Technology of Nuclear Installations, vol. 2012, pp. 1-20, 2012.

[26] D. Powers and S. Burson, "A simplified model of aerosol removal by containment sprays,” Tech. Rep. NUREG/CR-5966, 1993.

[27] K. Mehboob, K. Park, and R. Khan, "Quantification of incontainment fission products source term for 1000 MWe PWR under loss of coolant accident," Annals of Nuclear Energy, vol. 75, pp. 365-376, 2015.

[28] K. Jak, Nuclear power plant modeling and steam generator stability analysis [Ph.D. thesis], The University of Michigan, 1981.

[29] USNRC, "Reactor safety study. An assessment of accident risks in U. S. commercial nuclear power plants. Appendix XI. Analysis of comments on the draft WASH-1400 report. [PWR and BWR]," Tech. Rep. WASH-1400(App.11), 1975.

[30] USNRC, Severe Accident Risks: An Assessment for Five U.S, Nuclear Power Plants. NUREG-1150. U.S. Nuclear Regulatory Commission, S, 1990.

[31] J. Knudsen, Properties of Air-Steam Mixtures Containing Small Amounts of Iodine. BNWL-1326, Battelle Memorial Institute Pacific Northwest Laboratories Richland, Washington, Wash, USA, 1970.

[32] R. K. Hillard and L. F. Coleman, Fluid and energy system department, Physics and Engineering Division. AEC Research and development Report, BNWL-1457, Pacific North west Laboratories, 1970.

[33] L. Soffer et al., Accident Source Terms for Light-Water Nuclear Power Plants, NUREG-1465, U.S. Nuclear Regulatory Commission, 1995.

[34] USNRC, "Alternative Radiological Source Terms for Evaluating Design Basis Accidents at Nuclear Power Reactors, Regulatory Guide 1.183," 2000.

[35] K. Mehboob, C. Xinrong, R. Ahmed, and M. Ali, "Numerical simulation of radioisotope's dependency on containment performance for large dry PWR containment under severe accidents," Nuclear Engineering and Design, vol. 262, pp. 435451, 2013.

[36] K. Mehboob and M. S. Aljohani, "Modeling and simulation of radio-iodine released inside the containment as result of an accident," Progress in Nuclear Energy, vol. 88, pp. 75-87, 2016.

[37] L. Hu, Y. Zhang, L. Li, G. H. Su, W. Tian, and S. Qiu, "Investigation of severe accident scenario of PWR response to LOCA along with SBO," Progress in Nuclear Energy, vol. 83, pp. 159-166, 2015. 
[38] A. El-Jaby, B. J. Lewis, W. T. Thompson, F. Iglesias, and M. Ip, "A general model for predicting coolant activity behaviour for fuel-failure monitoring analysis," Journal of Nuclear Materials, vol. 399, no. 1, pp. 87-100, 2010.

[39] NUREG/CR-009, Technological bases for models of spray washout of airborne contaminants in containment vessels, U.S Nuclear Regulatory Commission, 1978.

[40] A. G. Croft, "A Users Manual for the," in ORIGEN2 Computer Code, Rep. ORNL/TM-7175, Oak Ridge National Laboratory, Oak Ridge, 1980.

[41] S. U. Kim and C. S. Kang, "Evaluation of Radioactive Source term in the System integrated Modular Advanced Reactor," The Korean Society of Nuclear Medicine, vol. 31, no. 1, p. 16, 1999.

[42] Y. Zhao, L. Zhang, and J. Tong, "Development of rapid atmospheric source term estimation system for AP1000 nuclear power plant," Progress in Nuclear Energy, vol. 81, pp. 264-275, 2015.

[43] E. Porcheron, P. Lemaitre, D. Marchand, W. Plumecocq, A. Nuboer, and J. Vendel, "Experimental and numerical approaches of aerosol removal in spray conditions for containment application," Nuclear Engineering and Design, vol. 240, no. 2, pp. 336-343, 2010.

[44] NUREG CR 0800, "Standard review plan for the review of safety analysis reports for nuclear power plants: LWR edition," U.S. Nuclear Regulatory Commission, 1978. 

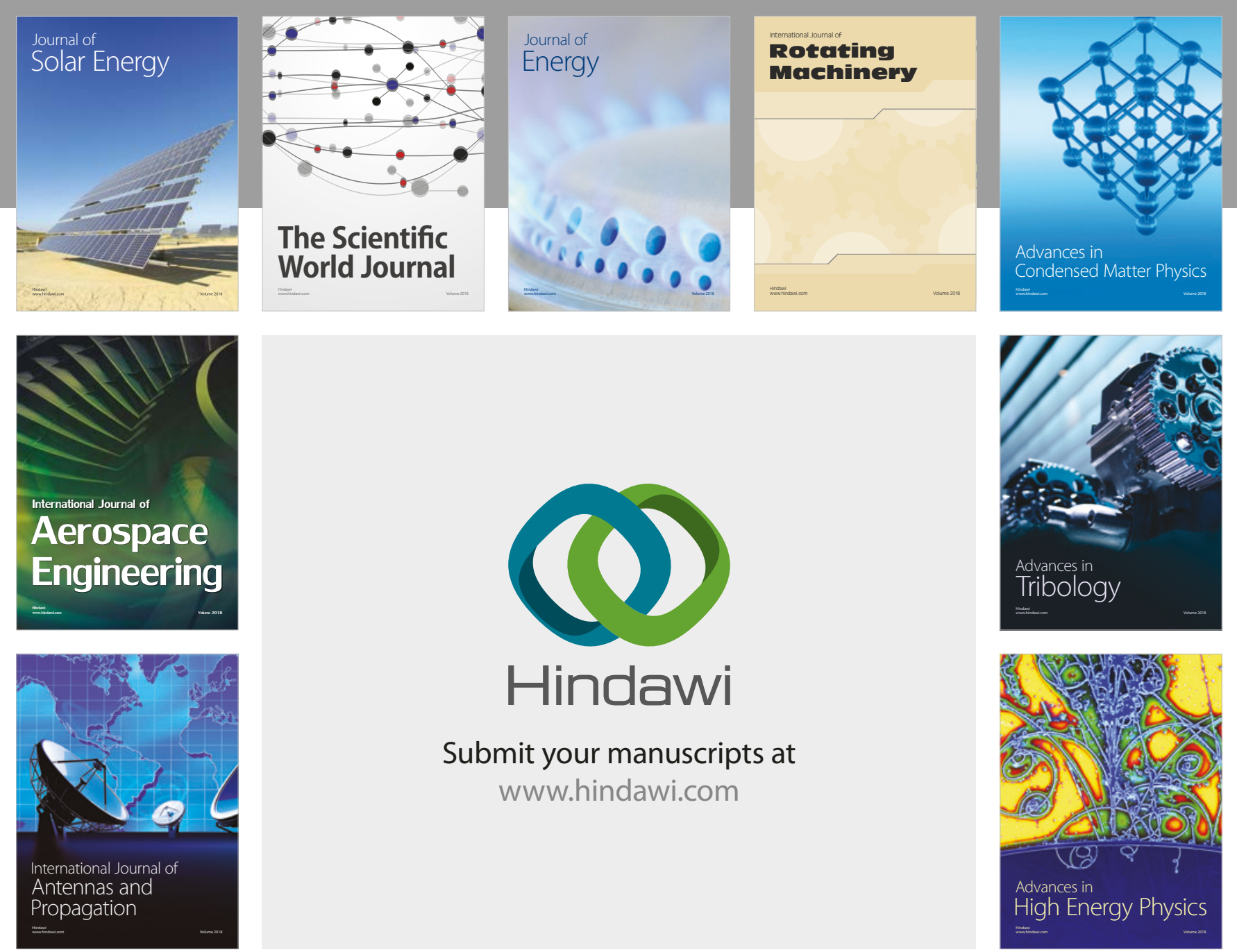

Submit your manuscripts at

www.hindawi.com
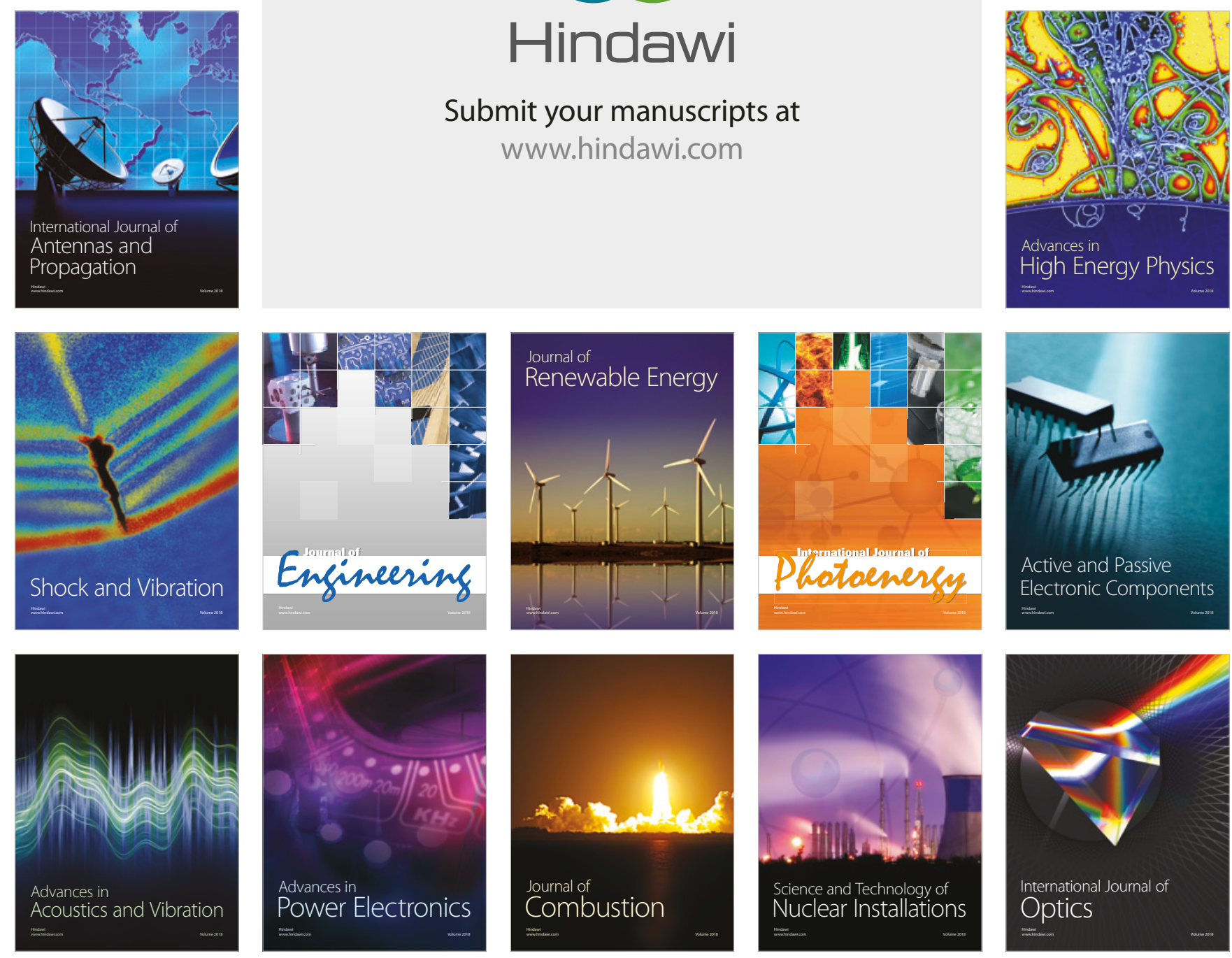